\title{
Gem Stones of the United States
}

GEOLOG I C A L S URVEY BULLETIN 1042 - G

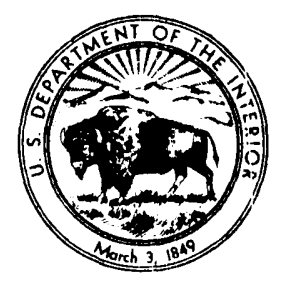





\title{
A CONTRIBUTION TO ECONOMIC GEOLOGY
}

\section{GEM STONES OF THE UNITED STATES}

\author{
By Dorothy M. Schlegel
}

\begin{abstract}
Many semiprecious, but few precious, gem stones have been found in the United States. Beauty, durability, and rarity are the most important qualities of a precious gem. Gem stones are distinguished by their physical properties: color, crystal form, cleavage, parting, hardness, specific gravity, luster, index of refraction, transparency, and dispersion. Gems are named for their color, type locality, outstanding physical property, or persons. The most popular gem cuts are the cabochon, rose, brilliant, step, and mixed. The carat, one-fifth of a gram or 200 milligrams, is the unit of weight measurement. The color of four popular gems may be changed by heat treatment or dyeing. Only the ruby, sapphire, spinel, emerald, rutile, and quartz of gem quality have been synthesized. The best quality of assembled stones are the doublet and triplet. Most gem stones are found in alluvial gravels and igneous rocks, especially granite and pegmatite deposits.
\end{abstract}

\section{INTRODUCTION}

Gem stones generally are divided into two categories: precious and semiprecious. A precious gem stone has beauty, durability, and rarity, whereas a semiprecious gem stone has only one or two of these qualities. The diamond, emerald, ruby, and sapphire are considered precious gems. Some opal is precious, but most varieties are semiprecious.

The beauty of a gem stone is determined by personal taste. In ancient times man preferred brightly colored, translucent or opaque stones. Today he prefers evenly tinted, transparent stones. The desired hues are blue, rose, green, and true canary yellow in the diamond; pigeon-blood red in the ruby; cornflower blue in the sapphire; and grass green in the emerald. Most diamonds, however, are colorless.

The durability of a gem stone depends upon its hardness and lack of ready cleavage. A gem must be sufficiently hard to resist abrasion by objects normally found in everyday life and by dust. It should also resist the chemicals with which it comes in contact. Cleavability is the tendency of certain gems to split in one direction more readily than in another.

Rarity is one of the most important factors in establishing the price of a gem stone. Such gems as the diamond and ruby are rare, in addition to being beautiful and durable, and therefore are very expensive. Although the deep red pyrope garnet closely resembles the ruby in color, there is no comparison in expense and popularity. 
The purpose of this report is to give the amateur gemmologist some of the important information available on the gem stones of the United States. Although the finest precious gems occur in foreign countries, a wide variety of semiprecious stones, and a few precious gems, have been found in the United States. About 50 major gems and the geology of their occurrence are described in this report. William F. Foshag, U. S. National Museum, has kindly reviewed the manuscript and made many valuable sugges tions. Dana's "A textbook of mineralogy" is the source of the chemical formulas.

\section{PHYSICAL PROPERTIES}

Physical properties are important aids in identifying gems. They are: color, crystal form, cleavage, parting, hardness, specific gravity, luster, index of refraction, transparency, and dispersion.

Color is the first property noticed in a gem stone. Minerals of constant chemical composition usually have definite, characteristic colors. Many minerals, however, have varying chemical compositions and therefore a wide range of colors. Impurities, such as iron, chromium, and copper, also tint the minerais. Care should be taken in using color as a means of gem identification because it is not a constant property in most minerals.

Most gem stones have certain crystal systems that form under favorable conditions of temperature and pressure. If the conditions of formation are unfavorable, an amorphous mass having no particular atomic arrangement results. The six crystal systems in which gem stones may form are: isometric, hexagonal, tetragonal, orthorhombic, monoclinic, and triclinic.

Cleavage is the tendency of certain gem stones, when struck in the proper place, to split in one direction more readily than in another and yield plane surfaces. These plane or cleavage.surfaces are parallel to some of the crystal faces of some gem stones. For example, diamonds may be cleaved in four directions parallel to the faces of an octahedron. Ready cleavage, however, can be a handicap; topaz and kunzite, for example, are difficult to cut into faceted gems because of this factor.

Certain minerals form planes of structural weakness if exposed to stress or pressure. These planes are known as parting. Twinned crystals and certain minerals that have been subjected to the critical pressure are usually affected in this manner.

Hardness is the resistance a gem stone offers to abrasion or scratching. 'The hardness of a gem stone may be determined by scratching it with another mineral or with a knife blade. This may mutilate the stone. A series of 10 minerals, known as Moh's scale of hardness, has been established to show relative degrees of hardness. 


\section{MOH'S SCALE OF HARDNESS}
1. Talc
6. Orthoclase
2. Gypsum
3. Calcite
7. Quartz
4. Fluorite
8. Topaz
5. Apatite
9. Corundum
10. Diamond

The numbers preceding each mineral indicate only increasing degrees of hardness, not actual values. For example, the diamond, rated as 10, is many times harder than corundum, rated as 9. Corundum is placed next to diamond only because it is the mineral nearest the diamond in hardness. Because much dust is composed of silica (quartz, 7 on Moh's scale) particles, a gem stone should be harder than quartz.

Some minerals are harder in one direction than another. When testing a gem for hardness, the gem stone should be rubbed against the test stone, not vice versa. Cut stones can be badly damaged by permitting several of different hardness to be carried in contact with one another.

The specific gravity of a mineral is the ratio between its weight and the weight of an equal volume of water at $4^{\circ} \mathrm{C}$. It is a constant property of all minerals of fixed compositior The amateur gemmologist need not determine the specific gravity accurately, but he should learn to compare the relative weights of stones.

Luster, the general appearance of a mineral in reflected light, is of two types: metallic and nonmetallic. Most gem stones are nonmetallic. Terms used to.describe nonmetallic lusters are: vitreous or glassy, resinous, pearly, greasy or waxy, silky, and adamantine or brilliant. Luster is influenced by the index of refraction, transparency, and dispersion of a gem stone.

When light rays pass from air into a denser medium, they are bent or refracted. The velocity of light is diminished in the denser medium. The ratio between the velocity of light in air and that in the gem stone is known as the index of refraction. If a gem is transparent, the maximum amount of light is refracted. In translucent or opaque stones only part of the light is refracted. Dispersion is the ability of a mineral to separate white light into colored rays. Because the degree of refraction for different colors of light differs with each mineral, certain minerals have a higher dispersion than others. The diamond owes its fiery brilliance to a high index of refraction and high dispersion.

\section{TECHNOLOGY}

\section{GEM NAMES}

In ancient times gem names were based principally on color. The term "ruby" was applied to all red stones: spinel, ruby, garnet, and rose tourmaline; the term "sapphire, " to lapis lazuli and other blue stones; the term "topaz," to all yellow stones; and 
the term "emerald," to chrysocolla and all other green stones (Smith, 1949, p. 175). Corundum was referred to as "oriental" because the first specimens were brought to Europe from the Orient. Modern nomenclature for gems is based on the color, type locality, or an outstanding physical property of the gem. Several gems, such as uvarovite and kunsite, have been named for persons.

\section{GEM CUTS}

Most gem stones used in jewelry must be cut to reveal their full brilliance. In ancient times a gem stone was treasured for its surface coloration rather than its brilliance; therefore, gems were merely polished and left in their natural state.

The oldest type of gem cut in use today is the cabochon or rounded cut introduced by the Romans (Smith, 1949, p. 141). The cabochon was used for colored stones, such as the emerald, ruby, sapphire, and garnet, but is now used only for starstones, cat's-eyes, opals, and generally opaque and imperfect stones.

The art of faceting a gem stone originated in India in the 15th century (Smith, 1949, p. 142). The first faceted gems were diamonds that had been haphazardly cut to disguise any flaws or carbon spots. In the early 17 th century the rose cut, a symmetrical form consisting of a flat base and a faceted top terminating in a low point, was invented and used for cutting large diamonds. This form was varied in the Dutch rose, Antwerp rose, and rose recoupée. The brilliant cut, consisting of 56 facets plus the table and culet, was invented at the end of the 17th century. It revealed the fiery brilliance of a diamond for the first time and is still the standard cut for the diamond. Modifications of the brilliant form are the jubilee cut ( 88 facets), English brilliant (30 facets), the marquise, and the drop form.

The other faceted forms are the step cut, used for emeralds and exceptionally good diamonds, and the mixed cut, a combination step cut and brilliant cut. The purpose of a step cut is to display the color of a gem rather than its brilliance. The depth of this cut varies with the depth of color in the stone. A darkcolored stone is lightened by a shallow cut, and a light-colored stone is darkened by a deep cut. The mixed cut is used to heighten the beauty of irregularly colored stones, such as tourmaline.

\section{UNIT OF WEIGHT}

The carat, meaning one-fifth of a gram or 200 milligrams, is used as the unit for weighing gem stones. The cost of a gem stone is the result of the price per carat multiplied by the weight. The price per carat of a precious stone increases with size.

\section{METHODS OF CHANGING COLOR IN GEM STONES}

The color of many gem stones may be partly altered or driven off completely by the use of heat. The atoms of the coloring agent 
are thereby permanently rearranged. Heat is used to produce some of the tints rarely found in nature. Yellow topaz from Brazil can be heated carefully and cooled to produce a permanent pink, resembling the rare, natural pink topaz. In a similar manner a colored zircon may be heat-treated and thereby become colorless or changed to a different color. Other stones that react to heat are: violet quartz (amethyst) changing to orange brown, smoky quartz to yellow, pale-green beryl to blue, violet corundum to rose pink, and yellow corundum to colorless.

Dyeing is another means of changing the natural color of a gem stone. This method is most often used in porous stones, such as the agate. The unattractive gray and pale shades may be changed chemically to bright red, green, and blue shades. The common dyeing procedure is to soak the agate in the desired chemical (nitric acid for red shades, nitrates and chromium salts for green shades, and certain cyanates and sulfates for blue shades). The Romans dyed agate by soaking it in honey, removing it from the liquid, and heating it; this produced black bands. Today the same effect is achieved by first soaking the agate in a sugar solution, and then in sulfuric acid to char the sugar.

\section{SYNTHETIC STONES}

Ruby, spinel, emerald, sapphire, star sapphire, star ruby, rutile, and quartz are gem stones that have been successfully synthesized. A reddish-green stone known as synthetic alexandrite is actually synthetic corundum. A stone of simple chemical composition generally is more easily synthesized than one of complex composition. Although the diamond has the simplest composition of any gem stone ( $C$, or carbon), synthetic gem diamonds have never been perfected; on February 15, 1955, the General Electric Co. synthesized some very small industrial diamonds. The ruby has a simple composition of $\mathrm{Al}_{2} \mathrm{O}_{3}$, or 2 molecules of aluminum and 3 molecules of oxygen. Synthetic gem rubies are made by growing a boule (or pear-shaped mass) composed of $\mathrm{Al}_{2} \mathrm{O}_{3}$. Although the boule does not resemble a natural ruby crystal, it possesses most of the physical properties of the natural stone. Sometimes the following distinctions can be made between synthetic and natural stones: natural stones contain cavities that are never spherical; synthetic stones are never perfectly uniform in structure; and the growth lines of a stone cut from a boule appear as curved striae under the microscope; natural stones sometimes have straight growth lines.

\section{IMITATION AND ASSEMBLED STONES}

Gems made of glass are known as imitation stones. Unlike synthetic gems, imitation stones resemble true gems only in color. Cheap imitations are made from bottle glass or lead glass; more exact imitations are made from special glass or paste. "Reconstructed gems" are prepared from inferior gem material. Two of the more exact "assembled stones" are the doublet and triplet.

$4126730-57-2$ 
The doublet consists of two different substances cemented together. The top of the stone may be quartz and the bottom, glass; or the top may be genuine sapphire, deficient in color, and the bottom, paste of bright blue to compensate for the pale color of the sapphire. The triplet is an assembled stone in which the top and bottom are rock crystal cemented with colored canada balsam. The doublet and triplet are easily detected by immersing them in an oil and thereby seeing the separate layers or by dissolving the canada balsam in boiling water, causing the pieces to separate, but ruining the stone.

\section{GEOLOGIC .OCCURRENCE}

Gem stones are found principally in igneous rocks and alluvial gravels, but also in sedimentary and metamorphic rocks. The finest gems are cut from large, perfect stones with even color distribution. Igneous rocks, such as granite, are formed deep in the earth's interior and some contain rifts and cavities where gem stones have formed under the proper conditions. In some places, molten masses of igneous rocks are forced into cracks of other rocks; forming veins or dikes. Some pegmatite dikes contain a variety of gem stones, such as tourmaline, beryl (emerald, aquamarine), spodumene (kunzite, hiddenite), zircon, and gem varieties of feldspar, topaz, and quartz. Gem stones may be weathered out from their matrix, washed away in streams, and eventually deposited as alluvial gravels. Opal and agate are formed from aqueous solutions. Diamonds are found in kimberlite, a rare volcanic rock.

\section{PRECIOUS GEMS}

\section{DIAMOND}

\section{Physical properties:}

Color: Usually colorless, pale yellow or pale brown; also gray and black, rarely green, blue, or pink.

Crystal form: Isometric (cubic, octahedron).

Cleavage: Perfect, parallel to octahedron faces.

Hardness: 10.

Specific gravity: $3: 516-3.525$.

Luster: Adamantine, also greasy.

The diamond has many unusual qualities: extreme hardness, high index of refraction, strong color dispersion, and fiery brilliance. Composed of pure carbon, it has the simplest composition of all gems.

In the United States, more than 50,000 diamonds have been found in kimberlite near Murfreesboro, Ark. Kimberlite is a dark, greenish-black igneous rock of the peridotite family. It is composed of partly altered olivine phenocrysts in a dense ground mass. The kimberlite in Arkansas occurs in four small areas the largest of which appears to be a volcanic neck. The kimberlite includes breccia and tuff and weathers to a soft, friable, yellowish or greenish mass and black soil in which most of the diamonds have been found. 
Elsewhere in the United States, diamonds have been reported in four regions: the Pacific Coast, Great Lakes, central Kentuckyeastern Tennessee, and the Atlantic Coast-Piedmont. The Pacific Coast diamonis are found in sand and gravel of riverbeds and streambeds, principally derived from rocks of the Sierra Nevada. Specific localities in California where diamonds have been found are: Smith River, Del Norte County; Trinity River, Trinity County; Spanish Creek and Gopher Hill, Plumas County; Placerville and Webber Hill, El Dorado County; Cherokee Flats, Yankee Hill, and Oroville, Butte County; French Corral, Nevada County; Indian Gulch and Volcano, Amador County; and Alpine Creek, Tulare County. Other western localities are: Diamond Basin, Ada County, Idaho; Curry County, Oreg.; and Nelson Hill, near Glacier County, Mont. The Great Lakes diamond region is essentially the terminal moraine of the last ice sheet. Diamonds have been found in Wisconsin at Plum Creek, Pierce County; Oregon, Dane County; Kohlsville, Washington County; Saukville, Ozaukee County; Eagle, Waukesha County; and Burlington, Racine County. Other localities in the Great Lakes region are Dowagiac, Cass County, Mich.; Lick Creek, Brown County, Ind.; and Milford, Clermont County, Ohio. Diamonds have been found in Kentucky at Cabin Fork Creek, Russell County, and in Tennessee at Clinch River, near Union Crossroads, Roane County; Luttrell, Flat Creek, Union County; and Koko Creek, Tellico River, Monroe County. In the Atlantic Coast-Piedmont region many diamonds have been found in sand and gravel deposits derived from nearby crystalline rocks. Specific localities in North Carolina are Brindletown Creek Ford, Burke County; the J. B. Twitty gold placer mine, Rutherford County; Cottage Home, Lincoln County; Todds Branch, Mecklenburg County; Muddy Creek, Dysortville, and near Dysortville, McDowell County; Kings Mountain, Cleveland County; and Portis gold mine, Franklin County. In South Carolina diamonds have been found in Spartanburg County; in Virginia, at Manchester, Chesterfield County; in Georgia, at Gainesville in Hall County, Horshaw mine in Acooche Valley, and Morrow Station in Clayton County; in Alabama, in Lee and Shelby Counties; and in West Virginia, at Peterstown. Diamonds have also been found in Huntsville, Tex.

$$
\begin{gathered}
\text { BERYL (EMERALD) } \\
\mathrm{Be}_{3} \mathrm{Al}_{2}\left(\mathrm{SiO}_{3}\right)_{6}
\end{gathered}
$$

Physical properties:

Color: Grass green.

Crystal form: Hexagonal.

Cleavage: Indistinct, parallel to basal face.

Hardness: 7.5.

Specific gravity: 2.63-2.80.

Luster: Vitreous.

Emerald is the only precious variety of beryl. Its grass-green color has been attributed to the presence of chromic oxide. Emerald crystallizes in a six-sided prism terminated by a basal face at right angles to the prism edge. It is faintly dichroic, 
showing a deeper color in one direction than another. The hardness of emerald is a little less than that of the other varieties of beryl. All varieties of beryl are brittle and therefore easily fractured. Most emeralds are badly flawed and no large, unflawed stone is known. Emeralds are usually step cut, but some are brilliant cut. A flawless stone of good quality and larger than 6 carats would have a much higher value than a diamond of equal size.

Emeralds occur in granitic rocks; such as silicic pegmatite, in high-temperature calcite veins, in crystalline schist, and in altered marble.

In North Carolina, emeralds have been found at the Emeraldhiddenite mine, Alexander County; Turner mine, Cleveland County; and the Emerald matrix mine, Crabtree Mountain, Mitchell County. None of these mines is active. At the Emerald-hiddenite mine emerald crystals of gem quality, associated with rutile crystals, black tourmaline, feldspar, quartz, hiddenite (blue-green gem variety of spodumene), and aquamarine, occurred in schleiren in gneiss. Only a few pegmatites are gem bearing. At the Turner mine, about a dozen emerald crystals of good grass-green color, associated with colorless and smoky quartz crystals and black tourmaline (Sterrett, 1909, p. 31), were found loose in the soil. The country rocks are schist and gneiss intruded by masses of granite. Only one pegmatite dike yielded a few small emerald crystals of pale green color. The emeralds occurred with quartz, feldspar, black tourmaline, and green beryl, in a red, clayey cavity. Most of the emeralds found at these two mines were flawed by scratches and silky internal markings. At the Emerald matrix mine the stones were flawed and pale. Occurrences of emerald also have been reported near the Bowen River, Cherokee County, S. C.

\section{CORUNDUM}

$$
\mathrm{Al}_{2} \mathrm{O}_{3}
$$

Ruby and sapphire

\section{Physical properties:}

Varieties: Sapphire (blue and all colors except red), ruby (red), star sapphire, star ruby.

Crystal form: Hexagonal.

Parting: Parallel to basal plane and unit rhombohedron.

Hardness: 9.

Specific gravity: $3.95-4.10$.

Luster: Adamantine to vitreous.

Ruby and sapphire are the important gem varieties of corundum. The color of the ruby ranges from rose to dark-purplish red. The dark red or "pigeon-blood" red is the most desirable. The sapphire ranges in color from blue to pink, yellow, and colorless with some green and violet varieties. The finest stones are "cornflower blue." Good color is important because corundum gems have low 
dispersion and, therefore, lack fire. Both stones are dichroic. The color of a ruby is thought to be caused by chromic oxide, and that of a sapphire by titanium oxide (Smith, 1949, p. 273). Radiation deepens color in these stones or creates color if they were previously colorless. When heated, a ruby turns green and retains this shade until almost cool at which time it regains its original red color. A star ruby or sapphire contains fibrous inclusions arranged in bundles $60^{\circ}$ apart. This starlike structure is best dis played when the stone is properly oriented and cut in deep cabochon.

The original sources of ruby and sapphire are metamorphic rocks, such as gneiss, schist, and marble, and igneous rocks, such as granite, nepheline-syenite, and peridotite. The gems are found in the parent rock or in placer deposits derived from these rocks. Commonly associated minerals are spinel, tourmaline, kyanite, magnetite, chlorite, and nepheline.

The only notable locality where rubies have been mined in the United States is Cowee Valley, Macon County, N. C. Here, the rubies probably were formed in a matrix of hormblende gneiss and pegmatite lenses in hornblende gneiss. Both the gneiss and pegmatite are badly weathered at the surface. In the decomposed pegmatite, pink to lilac-colored corundum is abundant, but little red corundum of gem quality has been found. Most of the gem material was obtained from nearby stream gravels. Associated minerals were all shades of corundum, ilmenite, rutile, kyanite, red and pink rhodolite garnet, and zircon. Gem rubies also have been found in the Calumet mine, Salida, Colo.; Marion Claim, Fremont County, Wyo.; and in Yogo Creek, Judith Basin County, Mont.

Sapphires have been mined in many localities in Montana; the largest mine is near Yogo Gulch, Judith Basin County. The sapphires occur in a nearly vertical igneous dike that intrudes gently dipping limestone. The dike rock is easily weathered to soft, yellow or gray clay at the surface and greenish-gray friable rock and blue clay at depth (Clabaugh, 1952, p. 11). The principal minerals in the dike rock are biotite mica and pyroxene (diopside variety) containing minute inclusions of calcite, quartz, pyroxene, and pyrite. Limestone fragments are abundant. The dike is irregular in shape and contains alternate zones of rich and barren rock (Sterrett, 1907, p. 30). The rock is barren where the dike is narrow (Clabaugh, 1952, p. 17). The color of the stones is uniform and ranges from light blue to cornflower blue. Other Montana sapphire deposits are the Missouri River deposits, northeast of Helena; the Rock Creek deposit, southwest of Philipsburg, Granite County; Dry Cottonwood Creek deposit, northwest of Butte, Deer Lodge County. Other Montana sapphire occurrences are Quartz Gulch, Granite County; Pole Creek, Madison County; Browns Gulch, Silver Bow County; and in Chouteau County (Clabaugh, 1952, p. 54-55).

Sapphire occurrences in other States have been reported at Barstow, San Bernardino County, Calif.; at the Calumet iron mine, Chaffee County, Colo.; several localities in Fremont County, Colo.; 
in Adams and Washington Counties, Idaho; Morgan County, Ind.; at the Sapphire and White Water mine, Jackson County, N. C.; and at Corundum Hill mine, Macon County, N. C.

\section{SEMIPRECIOUS GEMS}

\section{BERYL}

\section{Aquamarine, heliodor, morganite}

$$
\mathrm{Be}_{3} \mathrm{Al}_{2}\left(\mathrm{SiO}_{3}\right)_{6}
$$

\section{Physical properties:}

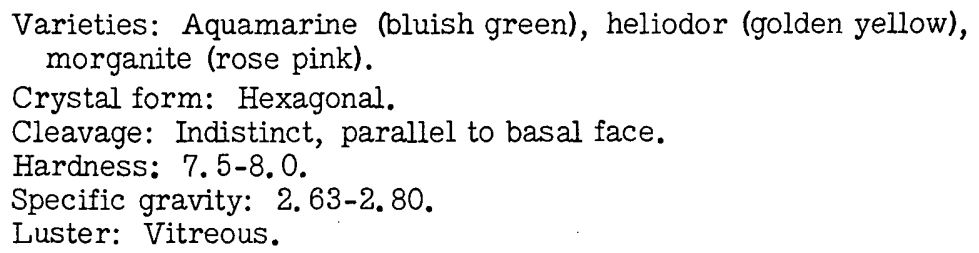

The semiprecious varieties of beryl are aquamarine, heliodor, and morganite. Aquamarine ranges in color from yellowish green to bluish green, heliodor is golden yellow, and morganite ranges from rose pink to rose red. Beryl also occurs in yellow, blue, and colorless crystals. The shades of aquamarine are probably due to the presence of ferric oxide; whereas those of morganite may be due to the presence of lithia; and the color of heliodor, to the presence of uranium oxide (Smith, 1949, p. 286). These varieties occur in larger quantities, bigger crystals, and have more uniform transparency than the emerald. Their beauty is best displayed in a step or mixed cut. The physical properties of beryl are discussed on page 209.

These varieties of beryl occur in granitic rocks, principally in pegmatite deposits. Aquamarine has been mined in Maine, Connecticut, California, New Hampshire, Colorado, Montana, Georgia, and North Carolina. Morganite and heliodor are rare in the United States. Salmon-pink beryl crystals of good quality, but few of true rose-red color, have been found in the Pala and Mesa Grande districts, San Diego County, Calif. Additional aquamarine localities are listed below:

California:

Colorado:

Connecticut:

Georgia:

Idaho:

Maine:
San Diego County, Ramona

Chaffee County, Mount Antero region Fremont County, Parkdale, Royal Gorge.

Litchfield County

Middlesex County, Portland, Haddam

Rabun County, Clayton, Highlands

Boise County, Centerville

$\mathrm{Nez}$ Perce County, Lewiston

Androscoggin County, Mount Apatite 
Maine-Cont. Oxford County, Albany, Buckfield, Grafton, Lovell, Norway, Paris, and Stoneham.

Sagadahoc County, Topsham

Maryland: Baltimore County, Arundel gneiss quarry.

Massachusetts: Hampshire County, Goshen

Worcester County, Fitchburg, Royalston.

New Hampshire: Grafton County, Grafton

North Carolina: Alexander County, Barrett Mountain Buncombe County, Asheville

Burke County, South Mountain

Caldwell County

Gaston County

Jackson County, Grimshawe mine, Montvale, R. E. Brown Prospect. Macon County, Littlefield mine, Tessentee Creek.

Madison County, Knapp's, Reed Creek Mitchell County; Bakersville

Yancey County, Burnsville, Ray Mica mine.

Pennsylvania: Delaware County, Avondale Montgomery County, Philadelphia area.

South Carolina: Anderson County, Anderson

South Dakota: Custer County, Black Hills

Utah:

Tooele County, Ibapah Mountain

Golden beryl has been found at the following localities:

California: - San Diego County, Pala district

Connecticut: Litchfield County, Litchfield

Maine:

Androscoggin County, Auburn, Mount Apatite, and Poland.

Maryland: $\quad$ Montgomery County, Burnt Mills Hills

New Hampshire: Grafton County, Grafton

Merrimack County, Danbury

Strafford County; Center Strafford Sullivan County, Acworth, Beryl Mountain.

New York: Westchester County, Bedford Village, North Castle.

North Carolina: Burke County, South Mountain

Occurrences of morganite have been reported at Simpson Springs, The Dugway Range, Utah, and at Hemet, Calif. It also has been recovered from pegmatite deposits in Maine. 
CHRYSOBERYL

$$
\mathrm{BeAl}_{2} \mathrm{O}_{4}
$$

Physical properties:

Varieties: Alexandrite (bluish green, deep olive green), cat'seye or cymophane (chatoyant).

Crystal form: Orthorhombic.

Cleavage: One, parallel to faces.

Hardness: 8.5.

Specific gravity: $3.50-3.84$.

Luster: Vitreous.

Chrysoberyl ranges in color from shades of yellow and brown to bluish green and deep olive green. Alexandrite, the greenish variety, has strong dichroism in columbine red, orange yellow, and emerald green. Cat's-eye or cymophane is a cloudy variety that is opalescent when properly oriented and cut en cabochon. Shades of yellow are caused by the presence of iron, and shades of green are probably caused by chromium. Chrysoberyl occurs in twinned, tabular crystals that lack brilliance. It is a hard gem stone, ranking 8.5 on Moh's scale. Cat's-eye is cabochon-cut, whereas alexandrite is brilliant- or step-cut. Chrysoberyl has not been synthesized. The so-called synthetic alexandrite is either synthetic corundum or synthetic spinel.

Chrysoberyl is a rare mineral that occurs in granitic rocks, silicic pegmatites, and mica schist. Most gem varieties, however, have been found in alluvial deposits derived therefrom. Very few occurrences of gem chrysoberyl have been reported in the United States. Localities are at Drew-Hill, Golden, Jefferson County, Colo.; Boulder County, Colo.; Haddam, Conn.; Ragged Jack Mountain, Conn.; Oxford County, Maine; and Greenfield, N.Y. The largest crystals of chrysoberyl in the United States were obtained from a pegmatite dike at Drew Hill, Golden, Colo. (Pearl, 1951, p. 77). The olive-green chrysoberyl was associated with quartz, muscovite, apatite, beryl, pyrite, and andradite.

\section{FEIDSPAR GROUP}

Amazonite: $\mathrm{KAlSi}_{3} \mathrm{O}_{8}$ (microcline).

Oligoclase: $90-70$ percent $\left[\mathrm{NaAlSi}_{3} \mathrm{O}_{8}\right]+10-30$ percent $\mathrm{CaAl}_{2} \mathrm{Si}_{2} \mathrm{O}_{8}$.

Labradorite: $50-30$ percent $\mathrm{NaAlSi}_{3} \mathrm{O}_{8}+50-70$ percent $\mathrm{CaA}_{2} \mathrm{Si}_{2} \mathrm{O}_{8}$ (plagioclase feldspar).

Moonstone: $\mathrm{KAlSi}_{3} \mathrm{O}_{8}$ and $\mathrm{NaAlSi}_{3} \mathrm{O}_{8}$ (albite and orthoclase).

Sunstone: $90-70$ percent $\left[\mathrm{KAlSi}_{3} \mathrm{O}_{8}\right]+10-30$ percent $\mathrm{CaAl} \mathrm{Si}_{2} \mathrm{O}_{8}$ (anorthite).

\section{Physical properties:}

Species: Amazonite (green); labradorite (white, gray, brown with play of colors); moonstone (whitish); oligoclase (clear); sunstone (whitish with reddish and yellowish rays).

Crystal form: Monoclinic (orthoclase); triclinic (albite, labradorite, microcline, and oligoclase). 
Physical properties-Continued

Cleavage: Excellent in two directions at $90^{\circ}$.

Hardness: $6.0-6.5$.

Specific gravity: 2.54-2.75.

Luster: Vitreous, sometimes pearly.

Amazonite, labradorite, moonstone, oligoclase, and sunstone belong to the mineral group known as the feldspar family. Amazonite is the green gem variety of microcline; labradorite is a plagioclase feldspar showing a play of colors, predominantly blue and green; moonstone is a white gem variety of albite and orthoclase; gem oligoclase occurs as clear glassy crystals; and sunstone is white oligoclase, orthoclase, microcline, albite, or labradorite with reddish and yellowish reflections. Although these gem stones are somewhat similar in chemical composition, they differ in physical properties. The difference in their cleavage angles is $1^{\circ}$. Their color dispersion is very low. Moonstone, the most valuable gem stone of this group, is composed of thin layers of orthoclase and albite (the soda feldspar). This linear arrangement gives the whitish stone a blue cast: the thinner the layers, the bluer the stone. If the layers are thick, the stone has a white sheen. Sunstone is oligoclase, orthoclase, microcline, albite, or labradorite containing minute scales of hematite. This feature is caused by reflections from crystals of an iron mineral, hematite or goethite, scattered throughout the stone. Both moonstone and sunstone are cut en cabochon. Labradorite displays many colors: blue, green, yellow, fire red, and pearl gray. This effect is probably caused by the interference of light from the reflection of thin inclusions of several minerals. Amazonite, the most abundant feldspar gem in the United States, ranges in color from bluish green to greenish gray. It is opaque. Most jewelers cut amazonite into beads or carve figures from it.

Feldspar gems occur in igneous rocks, especially in pegmatite dikes. Very few specimens of moonstone have been found in the United States. The principal localities have been the Rutherford mine, Amelia Court House, Va.; Mount Beckwith, Colo.; and Rialto, Funeral Mountains, Calif. Sunstone has been found in Pennsylvania at Feasterville, Bucks County; Nottingham Township, Chester County; and Mineral Hill, Media, Delaware County. In North Carolina it has been found at Medlock Mountain, Bakersville; and in Virginia, at Hewlett, Hanover County, and Amelia Court House, Amelia County. Amazonite has been produced commercially in Colorado near Pikes Peak, El Paso County, and in the Crystal Peak region near Florissant, Teller County; and in Virginia near Amelia Court House, Amelia County. Other localities where amazonite has been found are in Colorado at Deertrail, Arapahoe County, near Sedalia, Douglas County, in Custer County, in the St. Peter's Dome area, El Paso County, and in the Tarryall Mountains, Park County; in Maine, at Mount Desert, Hancock County, and at Mount Mica, Paris, Oxford County; in Massachusetts, at Rockport, Essex County; in New Mexico, Rio Arriba 
County; in North Carolina, at Burnsville, Yancey County; in Pennsylvania, at Media and Middletown, Delaware County; and in Texas, at Katemcy, Mason County.

The Pikes Peak region in Colorado is a famous collecting area for amazonite in the United States. The country rock is principally coarse biotite granite that has been cut by many pegmatites. Both the granite and pegmatites contain many cavities or pockets, some of which are lined with well-formed crystals of amazonite, smoky and clear quartz, some topaz, and phenacite (a colorless beryllium gem stone). The color of the Pikes Peak amazonite ranges from gray to bright green and may or may not be stained with iron minerals. Other associated minerals are microcline, albite, biotite, fluorite, columbite, goethite, hematite, limonite, and zircon.

The amazonite at the Rutherford mine, Amelia Court House, Va. , occurs in pegmatite dikes that cut biotite schist and gneiss. The dikes contain crystals of quartz, mica, and feldspar, large beryl crystals intergrown with feldspar, hyacinth-red spessartite garnet, and pale-purple fluorite. Labradorite occurs in the central Adirondack region, northern New York; the Byrd ranch, Alpine, Brewster County, Tex.; and Clear Lake, Millard County, Utah.

$$
\begin{gathered}
\text { GARNET FAMILY } \\
\mathrm{R}_{3} \mathrm{R}_{2}^{\prime \prime \prime}\left(\mathrm{SiO}_{4}\right)_{3} \mathrm{R}^{\prime \prime}=\mathrm{Ca}, \mathrm{Mg}, \mathrm{Fe}^{++}, \text {or } \mathrm{Mn}{ }^{++} \mathrm{R}^{\prime \prime \prime}=\mathrm{Al}, \\
\mathrm{Fe}{ }^{+++}, \mathrm{Cr}, \text { or } \mathrm{Ti}{ }^{+++}
\end{gathered}
$$

Physical properties:

Varieties: Grossularite (reddish orange); pyrope (fiery red); almandite (columbine red); spessartite (orange to deep red); andradite (demantoid, grass to emerald green; topazolite, wine yellow); uvarovite (emerald green); rhodolite (purple or pale red).

Crystal form: Isometric.

Hardness: $6.5-7.5$.

Specific gravity: $3.15-4.30$.

Luster: Vitreous, resinous (andradite is subadamantine).

The term garnet applies to a group of six minerals which are closely related. This group crystallizes in the isometric system. Its basic chemical formula is the same, but the elements in each garnet differ widely. This group is an isomorphous series in which several chemically similar elements freely replace each other in solid solution.

Garnets are divided into three groups: the aluminum garnets, including grossularite, pyrope, almandite, and spessartite; the iron garnet, andradite; and the chromium garnet, uvarovite. The popular gem garnets are the fiery-red pyrope, crimson and columbine-red almandite, and the emerald-green andradite. Grossularite is not often used for gems because its color is not pleasing and its transparency is imperfect. Deep-red spessartite is very rare and, therefore, not often available for gem purposes. Green uvarovite is never used for gems because it does not occur in crystals large enough to cut. 
Gross ularit e : cinnamon-stone, hyacinth oressonite: $\mathrm{Ca}_{3} \mathrm{Al}_{2}\left(\mathrm{SiO}_{4}\right)_{3}$.

The color of grossularite ranges from pale olive-green yellowish orange to reddish brown. Cinnamon-stone is the golden-yellow grossularite, and hyacinth or essonite is the orange and reddish-brown variety. The hardness of grossularite is 7.25 , a little harder than quartz. Its specific gravity is 3.53 .

P y rope: $\mathrm{Mg}_{3} \mathrm{Al}_{2}\left(\mathrm{SiO}_{4}\right)_{3}$.

The red color of pyrope in some stones resembles that of the ruby. Pyrope ranges from deep red to nearly black. Rhodolite is a rose-red and purple subvariety, having a composition of two parts pyrope and one part almandite. The hardness of pyrope is 7.5 , and its specific gravity is 3.51 .

Almandite (carbuncle): $\mathrm{Fe}_{3} \mathrm{Al}_{2}\left(\mathrm{SiO}_{4}\right)_{3}$.

Almandite, which has a variable chemical formula, grades into pyrope. Its color is deep crimson and violet or columbine red. Almandite ranks 7.5 on Moh's scale of hardness and is harder than the other garnets, with the exception of uvarovite. Its specific gravity is 4.25. Good-quality almandite is more expensive than pyrope. The carbuncle is a crimson-red almandite cut en cabochon.

Spessartite: $\mathrm{Mn}_{3} \mathrm{Al}_{2}\left(\mathrm{SiO}_{4}\right)_{3}$.

Spessartite is a beautiful aurora red or brownish red; it would be a very popular gem stone if it were not so rare. Its color may also be yellow or orange brown. The hardness of spessartite is 7.25, and its specific gravity is 4.18 .

Andradite (demantoid, topazolite): $\mathrm{Ca}_{3} \mathrm{Fe}_{2}\left(\mathrm{SiO}_{4}\right)_{3}$.

The iron garnet, andradite, is a common garnet, but its subvarieties, demantoid and topazolite, are gem materials. Common andradite ranges in color from wine, greenish yellow, brownish yellow, grayish, to dark green, and grayish black to black. Demantoid is emerald green and has a brilliant luster. It is the most valuable of all garnets. Topazolite is wine yellow and closely resembles some topaz in color. The specific gravity of andradite is 3.75, and its hardness is 6.5.

Uvarovite: $\mathrm{Ca}_{3} \mathrm{Cr}_{2}\left(\mathrm{SiO}_{4}\right)_{3}$.

The chromium garnet, uvarovite, is emerald green and has a vitreous luster. Its hardness is 7.5 , and its specific gravity ranges from 3.41 to 3.52 .

Garnet is a common and widely distributed accessory mineral. It is found in metamorphic rocks, such as mica schist, hornblende gneiss, and marble; in pegmatite dikes; in basic igneous rocks, such as dunite and peridotite; and rocks, such as serpentine, derived from them.

Grossularite and essonite are found chiefly with vesuvianite, wollastonite, diopside, and scapolite in marble and dolomite. This species and its subvariety are usually found in the contact zone of 
igneous intrusives with metamorphic rocks. Beautiful essonite has been found in Andover, Maine; at the Leiper quarry, Avondale, Pa. ; in Bakersville, N. C. ; in Silver City, N. Mex.; at the Calumet iron mine, Turret, Colo.; and in Dos Cabezas Springs, San Diego County, Calif. Grossularite crystals of no gem value have been found in Gila Canyon, Ariz. ; Tilly Foster mine, Brewster, N. Y.; and the Good Hope mine, Pala district, San Diego County, Calif.

Pyrope is characteristic of peridotite rocks and serpentines containing much magnesia and iron. The finest pyrope garnets have been found in gravels on the Navajo Indian Reservation in northwestern New Mexico and northeastern Arizona near Gypsum Valley (Sterrett, 1908, p. 25). Other localities are Deadwood Gulch, Boise County, Idaho; Elephant Gulch, Custer County, S. Dak. ; Rattlesnake Creek, Tulare County, Calif. ; Laurel Creek, Burke County, N. C. Rhodolite, the rose-red and purple subvariety, occurs in stream gravels in Mason Branch Valley, near Franklin, Jackson County, and Cowee Valley, Macon County, N. C. The gravels probably were derived from mica schist containing large amounts of biotite and bronzite (Sterrett, 1910, p. 27).

Almandite occurs in mica schist and other metamorphic rocks containing alumina and iron. In Avery, Burke, Caldwell, and Catawba Counties, N. C., it is incrusted with brown limonite. Deep-purple crystals have been found in placer gravels near Lewiston, Idaho. Other localities are Black Canon, Colorado River, Nev.; White Pine County, Nev.; Acworth, Grafton, and Hanover, N. H. ; Ruby Mountain, Canon City, and South Park, Colo.; Chester and Delaware Counties, Pa. ; and Gore Mountain, North Creek, N. Y.

Spessartite occurs in some granitic rocks, quartzite, and schist. At Ruby Mountain, Chaffee County, Colo., it is found with topaz in rhyolite. Other localities are Fairmount Park, Philadelphia, Pa.; Haddam, Conn.; Amelia Court House, Va.; and in San Juan County, Utah.

Andradite is a common constituent of volcanic rocks; associated minerals are nephelite and leucite. It also is found in limestone contact zones. The subvarieties, demantoid and topazolite, also occur in volcanic rocks but are not common. A few localities where common andradite has been found are in Lehigh County, Pa.; Franconia, N. H. ; and New Haven, Conn. Demantoid of gem quality has not been found in the United States, but topazolite has been obtained from Mount Sneffels, Colo. and Magnet Cove, Ark.

Uvarovite, the chromium garnet, occurs with chromite in serpentine and also in granular limestone. Small amounts have been found at Wood's chromite mine near Texas, Lancaster County, Pa.; at Tilly Foster mine, Brewster, N. Y.; at Green Valley, American River, Calif.; Jacksonville, Calif.; Clear Creek, Idria, San Benito County, Calif. ; and in the Graham Mountain, Ariz. 
JADE

Jadeite: $\quad \mathrm{NaAl}\left(\mathrm{SiO}_{3}\right)_{2}$

Nephrite: $\mathrm{Ca}_{2}(\mathrm{Mg}, \mathrm{Fe})_{5}(\mathrm{OH})_{2}\left(\mathrm{Si}_{4} \mathrm{O}_{12}\right)_{2}$

Physical properties:

\section{Jadeite Nephrite (tremolite or actinolite)}

Color: Apple green to nearly emerald White to dark green. green, bluish green, leek green, greenish white, and nearly white. Sometimes white containing spots of bright green.

Crystal form: Monoclinic.

Cleavage: Two perfect, at $90^{\circ}$.

Monoclinic.

Two perfect, mutually

Hardness: 6.5-7.0.

Specific gravity: 3.3-3.5. inclined at $120^{\circ}$.

Luster: Subvitreous, pearly on sur6. 0-6.5.

2. $96-3.10$. faces of cleavage.

Glistening.

The term jade includes jadeite, a pyroxene; and nephrite, an amphibole. Both minerals commonly are green, tough, and fibrous. Their toughness is caused by a complex interweaving of minute fibrous crystals. Jadeite and nephrite are usually found in compact masses and, rarely, in monoclinic crystals. Jadeite, the choicer and rarer jade, has a higher specific gravity and degree of hardness than nephrite. The highly prized emerald-green color of jadeite is due to the presence of chromium. The green shades in nephrite are caused by the presence of ferrous iron. The Chinese usually carve it into intricate patterns and use itfor rings, pendants, pins, and small statues.

Nephrite and jadeite are minerals of metamorphic origin. They rarely are found in place, usually occurring in boulders of pebbles in stream gravels. Where found in place, nephrite is associated with serpentine as rounded masses and with hornblende gneiss and schist; jadeite is associated with albite (feldspar) in pegmatite dikes that cut dark-green serpentine. Nephrite and jadeite rarely are found together. However, in 1950 they both were obtained from streanl gravels at the North Fork of the Eel River, Trinity County, Calif. The most famous nephrite locality in the United States is southeast of Lander, Wyo. Other nephrite localities are in Marin, Monterey, and Tulare Counties, Calif. Jadeite deposits are in Clear Creek, San Benito County, and in Cloverdale and Valley Ford, Sonoma County, Calif.

\section{LAPIS LAZULI}

Lazurite: $3 \mathrm{NaAlSiC}_{4} \cdot \mathrm{Na}_{2} \mathrm{~S}$

Hauynite: $3 \mathrm{NaAlSiO}_{4} \cdot \mathrm{CaSO}_{4}$

Physical properties:

Color: Deep azure blue, greenish blue.

Crystal form: Isometric. 


\section{Physical properties-Continued}

Cleavage: Imperfect to distinct dodecahedral.

Hardness: 5-6 (5.5-6.0, hauynite; 5. 0-5.5, lazurite).

Specific gravity: Variable.

Luster: Vitreous.

Lapis lazuli is a mixture of blue hauynite or lazurite, brassy yellow pyrite, and white calcite with minor amounts of diopside and mica. Lazurite and hauynite are isomorphous. A higher content of either mineral increases. the value of the lapis lazuli. Because it is too soft to be worn in rings, lapis lazuli is used for ornamental purposes, such as amulets, vases, table tops, and material for mosaics. It usually occurs in compact, massive form and in mottled colors of blue, yellow, and white.

Although the United States contains few deposits of lapis lazuli, two mines have yielded the gem; one is in Cascade Canyon, San Bernardino County, Calif., and the other is at Italian Mountain, Gunnison County, Colo. Lapis lazuli occurs among the crystalline limestone and dolomite that have been altered by heat and mineralizing solutions. Hauynite occurs only in igneous rocks containing insufficient silica to form feldspars, whereas lazurite occurs as a contact metamorphic mineral in limestone near a granitic contact.

\section{QUARTZ GROUP}

$$
\mathrm{SiO}_{2}
$$

Physical properties:

\section{Varieties:}

Coarsely crystalline:

Amethyst (purplish or bluish violet)

Cat's-eye-or tiger's-eye (chatoyant)

Citrine (yellow)

Milky quartz (milky white)

Quartz with mineral inclusions:

Aventurine (spangled)

Gold quartz

Prase (leek green)

Rutilated quartz (fibrous)

Quartz crystal (colorless)

Rose quartz (pink)

Smoky quartz, cairngorm (smoky yellow to brownish black).

Cryptocrystalline:

Agate (variegated with alternating bands of color)

Moss agate (chalcedony with impurities usually

$\mathrm{MnO}_{2}$ in mosslike patterns).

Onyx

Carnelian (red chalcedony)

Chrysoprase (apple-green chalcedony)

Heliotrope or bloodstone (green chalcedony with small red inclusions).

Jasper (chalcedony colored red by minute inclusions of hematite). 
Physical properties-Continued

Crystal form: Hexagonal.

Cleavage: None (conchoidal fracture).

Hardness: 7.

Specific gravity:

Coarsely crystalline varieties: 2.65-2.66.

Cryptocrystalline varieties: 2.58-2.64.

Luster: Vitreous, sometimes greasy, splendent.

The quartz group is divided into two parts: coarsely crystalline varieties composed of silica $\left(\mathrm{SiO}_{2}\right)$, and cryptocrystalline varieties composed of a mixture of minute quartz particles and hydrated silica in an amorphous form. The coarsely crystalline varieties, rock crystal and amethyst, are cut into gems and the cryptocrystalline varieties, agate and jasper, are used for ornamental purposes.

Quartz has a simple chemical composition: silicon dioxide $\left(\mathrm{SiO}_{2}\right)$. The beautiful colors of amethyst, citrine, and other varieties are caused by traces of metallic oxides in the basic composition. Quartz crystallizes in the rhombohedral division of the hexagonal system and is frequently twinned. An X-ray study of quartz indicates that its atomic structure is a spiral which causes the formation of right- and left-handed crystals. The specific gravity is constant in dense quartz but varies in quartz containing inclusions or cavities.

Quartz is one of the most abundant minerals in the earth's crust. It occurs in igneous rocks that have an excess of silica, such as granite, rhyolite, and pegmatite. It also occurs in gneiss and schist and may be deposited as vein material by hot silicabearing solutions.

\section{COARSELY CRYSTALIINE VARIETIES}

Amethyst ranges in color from pale orchid to deep purple and may owe its color to the presence of manganese or boron. The most valuable amethyst is reddish-violet. This gem stone is slightly fluorescent. When heat-treated, the color of some becomes a deep brown, then orange, and finally colorless. In the United States, the most important amethyst deposits are found in Clayton, Rabun County, Ga., and near Holbrook, Navajo County, Ariz. Other localities are in Amherst and Amelia Counties, Va.; Alexander, Lincoln, and Macon Counties, N. C.; the Keweenaw Peninsula, Mich.; in Jefferson County, Mont.; and Fremont County, Colo. Several minor occurrences have been found in southeastern Pennsylvania; at Pleasant Mountain and Denmark, Maine; at Indianapolis, Ind.; in Abbeville and Anderson Counties, S. C. ; at Paterson, N. J.; at Granite, Baltimore County, Md.; and in Llano County, Tex.

"Tiger's-eye" is a golden-brown variety of quartz pseudomorphic after crocidolite asbestos. The fibrous structure of the asbestos is retained. 
Citrine, the golden-yellow, transparent variety of quartz, owes its color to the presence of ferric oxide. Localities where citrine has been found are the Newman mine, Livermore, Calif.; at Tuscarora, Elko County, and Gold Mountain and Palmetto Canyon, Esmeralda County, Nev., and at Stony Point and Taylorsville in Alexander County, N. C.

Milky quartz is a translucent to opaque, white variety. It is a common vein mineral in igneous and metamorphic rocks. The color of milky quartz is the result of many tiny inclusions of water and liquid carbon dioxide and fractures; the apparent white color is caused by the reflection of light by the walls of the cavities. The milky color may be tinted red, yellow, yellowish brown, or bluish gray. In Buckfield, Maine, milky quartz crystals were found in one of the largest pockets of quartz crystals ever discovered in the United States (Dake, Fleener, and Wilson, 1938, p. 107). Boulders of milky quartz have been found in the glacial drift of Hlinois and other North Central States.

The term quartz with mineral inclusions pertains to all varieties of quartz that contain other minerals. Quartz may include such minerals as mutile, tourmaline, hornblende, epidote, actinolite, goethite, and many others because it is usually the last mineral to crystallize from a magma. The included crystals give a netlike or hairlike appearance to the stone. All varieties of quartz with rodlike inclusions are called sagenite; the included mineral is used in the name of the particular variety of sagenite. If rutile is included, the stone is known as "rutilated quartz;" if tourmaline is included, it is known as "tourmalinated quartz." Prase is a dull leek-green quartz containing actinolite inclusions. The finest domestic rutilated quartz was found in boulders near Hanover, N. H. Other localities are at Florissant, Colo.; in Alexander, Burke, Catawba, Iredell, and Randolph Counties, N. C. ; Amelia Court House, Va.; Lancaster County, Pa.; and the Calumet Hill Quarry, Cumberland, R. I. Tourmalinated quartz has been found at Paris, Maine, and Stony Point, N. C.

Quartz with spangled inclusions is known as aventurine. The included minerals are scales of shiny mica or hematite. The most familiar aventurine is of reddish-yellow color and has a coppery sheen. Only small quantities of aventurine have been found in the United States.

Native gold may occur as disseminated growths in crystalline quartz, chalcedony, and agate. Gold in translucent, white, or clear quartz has been found in Butte, Calaveras, El Dorado, Mariposa, Nevada, Placer, Sierra, Tuolumne, and Yuba Counties, Calif. Gold in chalcedony was obtained from the Republic mining district, Washington. An unusual deposit of gold in quartz with malachite was discovered at the Quartet mine, near Searchlight, Nev. Gold in black quartz has been found at the Sheep Ranch mine, Calaveras County, and Sutter Creek, Amador County, Calif.

Quartz crystal is the transparent, colorless variety of quartz. The two best-known localities of quartz crystal in the United States are near Hot Springs, Ark., and in Herkimer County, N. Y. 
In New York the crystals are commonly found in the soil above large cavities containing doubly terminating crystals. Most of the Herkimer County crystals were obtained from Middleville, Newport, and Little Falls, N. Y. In Saline, Garland, and Montgomery Counties, Ark., quartz crystals occur in the lining of cavities in sandstone and massive quartz. Other localities where quartz crystal has been found are Diamond Island, Portland Harbor, Maine; Diamond Hill and Cumberland Hill, R. I.; in Alexander, Burke, Catawba, and Surrey Counties, N. C.; Rome, Georgia; in Madison County, Ark.; Fayette County, Tex.; and South Royalton, Vt. Quartz crystal is common and has been found in nearly all States.

Rose quartz, the rose-red or pink massive variety of quartz owes its color to the presence of manganese or titanium; this variety rarely occurs in crystal form. The only known discoveries of rose quartz crystals in the United States were made at Paris and Newry, Maine, and Grand Rapids, Mich. (Dake, Fleener, and Wilson, 1938, p. 108). Rose quartz commonly occurs as partly translucent masses in pegmatite veins. One of the largest deposits is located in the Black Hills, near Custer, S. Dak. Other localities are Albany, Maine; Southbury, Conn.; Westchester, N. Y.; Ashe and Stokes Counties, N. C. ; Roaring Fork, Pitkin County, Colo.; and Tuscarora, Moray, Carlin, and Silver Peak, Nev. Current production is from the Black Hills region, S. Dak., and the Pala, Mesa Grande, and Ramona districts, San Diego County, Calif.

Smoky quartz is the smoky-yellow to dark smoky-brown variety of coarsely crystalline quartz. Cairngorm is the smoky-yellow quartz made famous in Scotland. Its smoky appearance is thought to be the result of radium exposure to colorless quartz crystals (Dake, Fleener, and Wilson, 1938, p. 92). The best known locality in the United States for smoky quartz probably is the Pikes Peak region in Colorado where the crystals occur in association with amazonite and other gem stones in pockets of coarse granite. Other localities are Mount Antero summit, Colo. ; Helena, Mont.; Alexander, Burke, and Catawba Counties, N. C.; Herkimer County, N. Y.; Goshen, Mass.; Blueberry Hill, in Stoneham, Minot, and Mount Pleasant in Maine; Montgomery County, Pa. ; Iron Mountain, Missouri; and Magnet Cove, Arkansas.

\section{CRYPTOCRYSTALLINE VARIETIES}

All cryptocrystalline varieties are a form of chalcedony, the general term applied to gray or dark masses of silica that are almost opaque. Cryptocrystalline varieties of quartz are tougher than the coarsely crystalline varieties because they are composed of many closely bound small crystals and amorphous particles. Hardness and specific gravity also vary slightly in the cryptocrystalline group.

Agate is variegated chalcedony containing colorful bands in a concentric arrangement. The most common colors of agate are 
red, yellow, brown, green, blue, gray, and black. These colors are the result of the presence of small amounts of metallic salts or iron or manganese oxides and, rarely, nickel, chromium, and copper. The luster is sometimes waxy. Varieties of agate are: "banded agate," bands appearing three-dimensional and arranged in a wall-within-wall structure; "moss agate, " dendritic patterns of manganese dioxide, iron oxide, or chlorite fibers included in white or clear masses of silica; "iris agate, " apparently colorless until proper light reveals rainbow colors caused by the diffraction of light from closely spaced parallel layers; and silicified trees. Onyx is opaque agate with parallel alternating layers of different colors; the layers are straight lines of uniform thickness. Onyx should not be confused with Mexican onyx, a banded marble. Agate is a secondary mineral that fills seams, fissures, veins, and cavities in rock. It may also occur as stalactitic and botryoidal growths. Most agates are found in gravel deposits. The most important States where agates are obtained are central and eastern Oregon, Montana, Wyoming, Arizona, Texas, New Mexico, Washington, Utah, and Illinois. For exact localities consult $T$ he A g a te $B$ ook, by H. C. Dake.

Carnelian or sard is a clear, translucent agate ranging in color from yellow to red. It has been found in Jenne Creek, Hornbrook, Calif.; Salmon River and Cedar Creek, near Toledo, Oreg.; and in the Nehalem River, Vernonia, Oreg.

Chrysoprase is the apple-green, translucent variety of chalcedony. The color may range from bluish green to yellowish green, the result of the presence of nickel. Chrysoprase is usually associated with silicified nickel deposits. Because nickel deposits are scarce in the United States, chrysoprase is rare. Localities where it has been found are Nickel Mountain in western Oregon; near Visalia, Calif.; Buncombe and Macon Counties, N. C.; Chester County, Pa.; Garfield County, Colo.; St. Lawrence County, N. Y.; and Gila and Mohave Counties, Ariz.

Heliotrope or bloodstone is dark green, translucent chalcedony containing blood-red spots of jasper. The green color is due to chlorite and possibly iron, and the red color, to hematite. The few occurrences of heliotrope in the United States are at Newport Beach, Oreg.; in Chatham County, Ga.; near Uncompahgre, Colo.; and in Albany and Orange Counties, N. Y.

The term jasper includes nearly all varieties of impure, opaque, colored, amorphous quartz. Jasper may be red, yellow, brown, green, bluish, or black. These colors are due to minute inclusions of impurities; for example, iron. Jasper is formed in veins near lava flows. However, it is usualiy obtained from gravel deposits far from its original locality. It is widely distributed in the United States, especially in the Western States. The largest jasper deposit in the world is in the Petrified Forest, Ariz. One of the most famous jasper localities is the Morgan Hill district, Santa Clara County, Calif. Here the jasper is bright red containing circular areas of white and gray, and therefore is known as 
orbicular jasper. Other localities are Collyer, Trego County, Kans.; Berkshire Hills, Rowley, and Chester, Mass.; and along the Hudson River in Orange County, N. Y. In Pennsylvania many specimens have been found along the Delaware and Schuylkill Rivers, near Reading; in Chester and Lancaster Counties; and near Bethlehem and at Jim Thorpe (Mauch Chunk). In North Carolina jasper has been found at Granville; Reed's Creek, Madison County; and in Moore and Wake Counties. Jasper has also been found near Sullivan City and Laredo, Tex.; San Bernardino and Shasta Counties, Calif. ; and near Morrison, Hot Spring County, Ark.

\section{OPAL \\ $\mathrm{SiO}_{2} \cdot n \mathrm{H}_{2} \mathrm{O}$}

Physical properties:

Varieties: White opal, black opal, fire opal (reddish or orange), water opal (colorless), hydrophane.

Crystal form: None (amorphous).

Cleavage: None (conchoidal fracture).

Hardness: $5.5-6.5$.

Specific gravity: 1.9-2.3.

Luster: Vitreous to resinous pearly (common opal is waxy).

Opal may be precious but most varieties are semiprecious. It is a semitransparent stone having a vivid display of colors. When pure, opal is colorless; when impure, it may be red, yellow, green, blue, or black. It is an amorphous form of hydrated silica containing varying amounts of water. It is composed of a series of very thin films or layers which differ in refractivity. Opal appears to be a solidified mass of milky glass, but when light strikes the stone at certain angles, flashing colors are revealed. This phenomenon is known as opalescence. The colors are believed to be caused by the different refractivities of light in the thin layers; the thinner and more uniform the layers, the more beautiful the colors. Opal is a soft gem stone and therefore must be worn with care. Hydrophane, the opaque variety of common opal, is very porous and will absorb any liquid. Other varieties are less porous but will absorb some liquid. Wearers of opal should keep the stone away from dirty water, ink, or colored fluids. Heat evaporates the water in opal and therefore causes the stone to shatter or to lose its color. The value of opal is determined by its principal color, uniformity of structure, and beauty of opalescence. True black opals with good opalescence are the most valuable.

Opal occurs as a secondary mineral associated with volcanic rocks. It is also found in seams and fissures of sedimentary, igneous, and metamorphic rocks. The forms of opal range from massive, botryoidal, stalactitic to earthy, depending upon how the silica was deposited. Very little precious opal has been found in the United States, but common opal has been obtained from New York, New Jersey, North Carolina, Georgia, Florida, and Oregon. 
The best-known deposit of precious opal in the United States is in Virgin Valley, Humboldt County, Nev. The opals are obtained from thin seams of volcanic ash in the bottom of Tertiary lake. The gem material occurs as opalized wood which appears to be driftwood that was covered by volcanic ash and completely petrified by opaline solutions. The greatest variety of opals in the world is found here (Dake, Fleener, and Wilson, 1938, p. 249). Other localities for precious opal in the United States are in lava flows of the Columbia Plateaus in Washington, Idaho, and Oregon.

\section{SPODUMENE}

\section{Kunzite and hiddenite}

$$
\mathrm{LiAl}\left(\mathrm{SiO}_{3}\right)_{2}
$$

Physical properties:

Varieties: Kunzite (bluish pink to lilac pink), hiddenite (emerald green).

Crystal form: Monoclinic.

Cleavage: Two perfect, prismatic cleavages and one good parting.

Hardness: $6.5-7.0$.

Specific gravity: 3.13-3.20.

Luster: Vitreous.

Kunzite and hiddenite are the rare, transparent varieties of spodumene. Kunzite ranges in color from bluish pink to lilac pink; hiddenite ranges in color from yellowish green to emerald green. The color of kunzite fades upon long exposure to light. Common spodumene is white, yellow, or green. Spodumene usually occurs as deeply striated, monoclinic prisms that are often twinned. Most spodumene is opaque. Perhaps the rapid weathering of spodumene explains the reason so few deposits of its gem varieties have been found.

Spodumene occurs in very large crystals in pegmatite dikes. The most notable locality for kunzite is in the Pala district, San Diego County, Calif. The gem occurs with other lithia minerals in a series of broad, uniform pegmatite dikes. Kunzite is found in the core of the pegmatite, generally in a very coarse-grained quartz-spodumene unit. Quartz is the common associate, but cleavelandite, muscovite, and lepidolite also are found with it. Gem-quality crystals usually are enclosed in clay and a few occur loose at the bottom of voids or pockets. Most gem crystals are less than 2 inches long but some are nearly 15 inches long and weigh 24 ounces or more. Kunzite also has been found at Cohuila Mountain, Riverside County, Calif.; Spruce Pine, N. C.; Branchville, Conn.; and Andover, Maine.

The first reported locality for hiddenite in the United States is Stony Point, Alexander County, N. C. It has since been found in pegmatites of the Black Hills, S. Dak. It occurs with emerald and quartz in pockets of pegmatite dikes (see p. 210). 
TOPAZ

$$
\left[\mathrm{Al}(\mathrm{F}, \mathrm{OH})_{2}\right] \mathrm{AlSiO}_{4}
$$

\section{Physical properties:}

Color: Colorless and pale brown, blue, and pinkish shades of yellow.

Crystal form: Orthorhombic.

Cleavage: Perfect, parallel to basal face.

Hardness: 8.

Specific gravity: $3.4-3,6$.

Luster: Vitreous.

The most prized colors in topaz are reddish pink and wine yellow. The natural reddish-pink topaz is very rare. However, brownish-yellow topaz from Brazil may easily be transformed to a pink shade by application of heat. The pink color is permanent because the heat changes the atomic structure of topaz. Application of heat is most effective on Brazilian stones. Topaz may contain inclusions of liquid carbon dioxide. Yellow topaz is faintly dichroic and pink topaz is very dichroic in reddish-yellow and pinkish-yellow shades. Gem topaz is transparent and vitreous, but notbrilliant. The stone must be handled carefully by the gem cutter, and it is usually brilliant-cut in front and step-cut in back.

Topaz occurs in pegmatite dikes and in cavities in granite. It is formed by the action of hot acidvapors on rocks rich in aluminum silicates. It is commonly associated with minerals of similar origin such as fluorite, cassiterite, and tourmaline. Colorless and bluish transparent topaz has been found in California, Colorado, Utah, and New Hampshire. In San Diego County, Calif., bothblue and yellow varieties have been found; colorless and sherry-brown topazes were obtained in the Thomas Mountain district of Utah. Other localities are Nathrop, Colo.; Tarryall Mountains, north of Lake George, Colo.; North Chatham, N. H.; Streeter, Mason County, Tex.; and Topsham, Maine.

\section{TOURMALINE}

\section{(Complex sodium-aluminum borosilicate)}

\section{Physical properties:}

Varieties: Achroite (colorless), indicolite (indigo blue), rubellite (reddish), siberite (violet red), schorl (black).

Crystal form: Hexagonal.

Cleavage: None.

Hardness: 7.0-7.5.

Specific gravity: 2.98-3.20.

Luster: Vitreous to resinous.

Tourmaline occurs in a great variety of colors ranging from rose red (rubellite) and violet red (siberite) to indigo blue (indicolite), green, yellow, brown, and black (schorl). A colorless variety known as achroite is very rare. Tourmaline may have more than one color in a single crystal. If so, the colors usually are strongly contrasting and in many crystals have abrupt boundaries. The 
colors may be separated in a plane perpendicular to the length of the crystal or arranged in cylindrical zones. Watermelon tourmaline, having a pink core and green exterior, is an example of cylindrical color arrangement. In some crystals, the colors are reversed. Tourmaline is found in almost every color except sapphire blue and emerald green. The chemical composition of tourmaline is a complex borosilicate containing varying amounts of sodium, potassium, calcium, magnesium, lithium, fluorine, and hydrogen. On the basis of its composition tourmaline may be divided into three types which grade into one another:

1. Alkali tourmaline containing sodium, potassium, and lithium. Example, rubellite.

2. Magnesium tourmaline containing much; magnesium. Example, achroite and brown varieties.

3. Iron tourmaline containing much iron. Example, schorl.

Vitreous, clear, and transparent alkali tourmalines furnish the best gem material. The prismatic crystals are striated and have a different type of termination at each end. In cross section the crystals have a rounded, triangular shape. Dichroism is strong in the brown and green varieties. In order to permit the maximum amount of light to enter the stone, most tourmaline must be cut so that a facet perpendicular to the table is nearly at right angles to the length of the crystal.' Tourmaline is usually brilliant-cut in front and step-cut in back; fibrous varieties are cut en cabochon to display their chatoyancy (cat's-eye effect). Fractures are common in many tourmalines. The specific gravity varies with the color: the specific gravity of red stones ranges from 3.01 to 3.06 , and of black stones, from 3.11 to 3.20 . Tourmaline is fairly soft and therefore should not be set in a ring.

Tourmaline occurs as an accessory mineral in the acidic rocks, granite and pegmatite; and in the metamorphic rocks, schist and crystalline limestone. It is formed at high temperatures and pressures in the presence of vapors high in boron and fluorine. Rubellite, the lithia tourmaline, is usually associated with lithia-bearing muscovite and lepidolite. Most varieties of tourmaline occur in pegmatite deposits where they are associated with feldspar, quartz, and muscovite. The magnesian tourmaline, however, is found in limestone. Black tourmaline is a common accessory mineral in metamorphic rocks. In the United States excellent gem tourmaline has been found in the Pala, Mesa Grande, Rincon, and Ramona districts, San Diego County, Calif.; and at Mount Mica near Paris, at Mount Apatite near Auburn, Mount Rubellite, Rumford Falls, and Hebron, Maine. Other gem tourmaline localities in the United States are Royal Gorge and Pikes Peak districts, Colo.; Riverside County, Calif.; and Haddam, Conn. Dark-colored tourmaline crystals have been obtained from Cochise, Coconino, Maricopa, Pima, Pinal, Yavapai, and Yuma Counties, Ariz.; Chesterfield and Goshen, Mass.; Gouverneur, Dekalb, and Pierrepont, N. Y. ; and Chester County, Pa.

In San Diego County, Calif. , many transparent tourmaline crys tals of green, blue, yellow, and red were obtained from pockets in pegmatite dikes. Kunzite is associated with the tourmaline. 
TURQUOISE

$$
\mathrm{CuO} \cdot 3 \mathrm{Al}_{2} \mathrm{O}_{3} \cdot 2 \mathrm{P}_{2} \mathrm{O}_{5} \cdot 9 \mathrm{H}_{2} \mathrm{O}
$$

\section{Physical properties:}

Color: Blue, blue green, green.

Crystal form: Triclinic.

Hardness: 6.

Specific gravity: 2.60-2.83 (not constant due to porosity).

Luster: Waxy.

Turquoise, the favorite gem stone of the American Indians, is an opaque mineral ranging in color from sky blue to bluish green to green. The preferred color, sky blue, is typical of specimens containing no iron; the greenish shades are due to the presence of iron. Turquoise usually occurs in compact, cryptocrystalline masses. It has a porous structure and therefore should be protected from grease, moisture, and dirt. Sunlight and heat also have destructive effects on the stone. It is a fairly soft, yet tough, gem stone and is usually cut en cabochon and mounted in brooches, earrings, necklaces, and rings.

Turquoise is a secondary mineral found in thin veins and small masses in highly altered rocks. It is associated with limonite, quartz, feldspar, sericite, and kaolin. In the United States most of the sky blue turquoise deposits have been mined out, but greenish stones are still being obtained from localities in Arizona, New Mexico, and Colorado. At Turquoise Mountain and Ithaca Peak, Mineral Park, Ariz., turquoise is found in joints and fissures of a highly kaolinized quartz porphyry. Some of the turquoise appears to have been deposited from hot solutions in the quartz porphyry and others seem to be replacements of feldspar and kaolin. In the Castle Dome mine, Gila County, Ariz., turquoise is found in the leached zone of the porphyry copper deposit. In New Mexico the most notable locality is at Los Cerrillos, Santa Fe County, where turquoise is found in thin veins and small nuggets in a yellowish-white tuffaceous rock with gold-bearing quartz. Other New Mexico localities are in the Burro Mountains near Silver City, Little Hachita Mountains, Grant County, and the Jarilla Mountains, Otero County. The largest turquoise deposits in the United States are in the King mine of the San Luis Valley, Colo. Other localities are Tombstone, Cochise County and Pierce, Maricopa County, Ariz. ; near Baker, San Bernardino County, and Chowchilla River, Fresno County, Calif. ; Lake and Mineral Counties, Colo.; Esmeralda County, Battle Mountain, Lander County and Tonopah, Nye County, Nev. ; Somerville, N. J.; and Culberson County, Tex. In the United States the only known crystals of turquoise were found in Campbell County, Va.

OTHER COPPER GEM MINERALS

\begin{tabular}{|c|c|c|c|}
\hline & Azurite & Malachite & Chrysocolla \\
\hline Chemical composition. & $2 \mathrm{CuCO}_{3} \cdot \mathrm{Cu}(\mathrm{OH})_{2}$ & $\mathrm{CuCO}_{3} \cdot \mathrm{Cu}(\mathrm{OH})_{2}$ & $\mathrm{CuSiO}_{3} \cdot 2 \mathrm{H}_{2} \mathrm{O}$ \\
\hline $\begin{array}{l}\text { Physical properties: } \\
\text { Color }\end{array}$ & $\begin{array}{l}\text { Various shades of } \\
\text { azure blue. }\end{array}$ & & $\begin{array}{l}\text { Green to greenish } \\
\text { blue to blue. }\end{array}$ \\
\hline
\end{tabular}


Table-Continued

\begin{tabular}{|c|c|c|c|}
\hline \multirow{2}{*}{\multicolumn{2}{|c|}{ Physical properties-Continued: }} & Malacbite & Chrysocolla \\
\hline & & \multirow{3}{*}{$\begin{array}{l}\text { Monoclinic ............ } \\
\text { Perfect basal..... }\end{array}$} & \multirow{5}{*}{$\begin{array}{l}\text { Cryptocrystalline. } \\
\text { None, conchoidal } \\
\text { fracture. } \\
2-4 . \\
2.00-2.24 . \\
\text { Vitreous, shining, } \\
\text { earthy. }\end{array}$} \\
\hline Crystal form.......... & Monoclinic & & \\
\hline & Two indistinct.......... & & \\
\hline $\begin{array}{l}\text { Hardness.... } \\
\text { Specific } a r\end{array}$ & $\begin{array}{l}3.5-4.0 \\
3.77-3.89\end{array}$ & $\begin{array}{l}3.5-4.0 \\
3.90-4.03\end{array}$ & \\
\hline Luster & $\begin{array}{l}\text { Vitreous, almost } \\
\text { adamantine. }\end{array}$ & $\begin{array}{l}\text { Adamantine to } \\
\text { vitreous, silky, } \\
\text { dull. }\end{array}$ & \\
\hline
\end{tabular}

Azurite, the azure-blue copper carbonate, occurs in prismatic crystals and radiating spherical groups. It is similar in composition to the green copper carbonate, malachite. Both stones are soft and opaque. Azurite has a lower specific gravity than malachite and is not as common. It is a secondary mineral found in oxidized parts of copper veins with malachite, cuprite, native copper, iron oxides, and various sulfides of copper and iron. The country rock is commonly limestone. Localities in the United States where gem azurite has been found are at the Copper Queen mine in Bisbee, Courtland, Mineral Park, Morenci, and Superior, Ariz.; Las Vegas, Nev.; and the La Sal district, Utah.

Malachite is bright green in color and commonly occurs in botryoidal or stalactitic masses. It rarely is found in well-formed crystals, but it may be pseudomorphous after azurite. Malachite has a perfect basal cleavage. Its luster varies from adamantine to vitreous in crystals, silky in fibrous types, and dull in earthy varieties. The geologic occurrence and localities of malachite are the same as azurite. Both minerals are used for ornamental purposes.

Chrysocolla, a hydrous copper silicate, ranges in color from green to greenish blue. It is amorphous and usually occurs in opaque, compact masses. Its chemical composition is variable. It is distinguished from turquoise by inferior hardness. It may have a vitreous or earthy luster. Chrysocolla also is a secondary mineral found in oxidized zones of copper veins. Common associates are azurite, malachite, and other copper minerals. It is found in the copper districts of Arizona and New Mexico.

A list of journals on gems is given below:

Pacific Mineralogist, 6731 Arbutus Ave., Huntington Park, Calif. (ceased).

The Mineralogist, Couch Bldg., Portland, Oreg. (monthly).

The Earth Science Digest. Revere, Mass. (monthly). Gems and Gemmology, Gemmological Inst. America, Los Angeles (quarterly).

The Gemmologist, National Assoc. of Goldsmiths Press, London (monthly).

The Lapidary Journal, Lapidary Journal, Inc., P. O. Box 1228, Hollywood 28, Calif. (quarterly).

The Mineral Hobbyist, State Mineral Soc. of Texas, Austin, Tex. (ceased).

Rocks and Minerals, Rocks and Minerals Assoc., Peekskill, N. Y. (6 times a year). 


\section{GEOGRAPHIC DISTRIBUTION OF DEPOSITS OF PRINCIPAL GEM STONES}

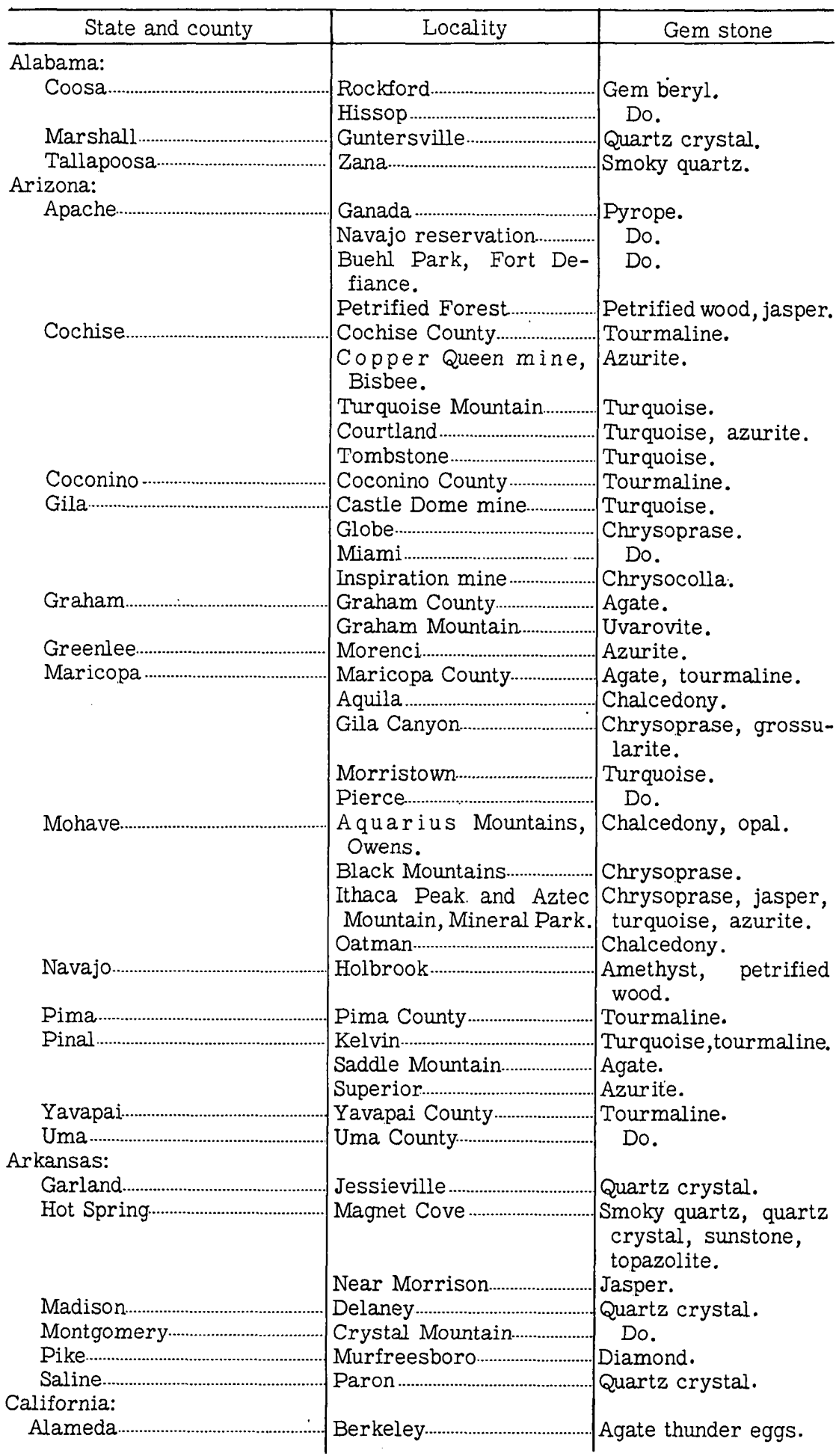


Table-Continued

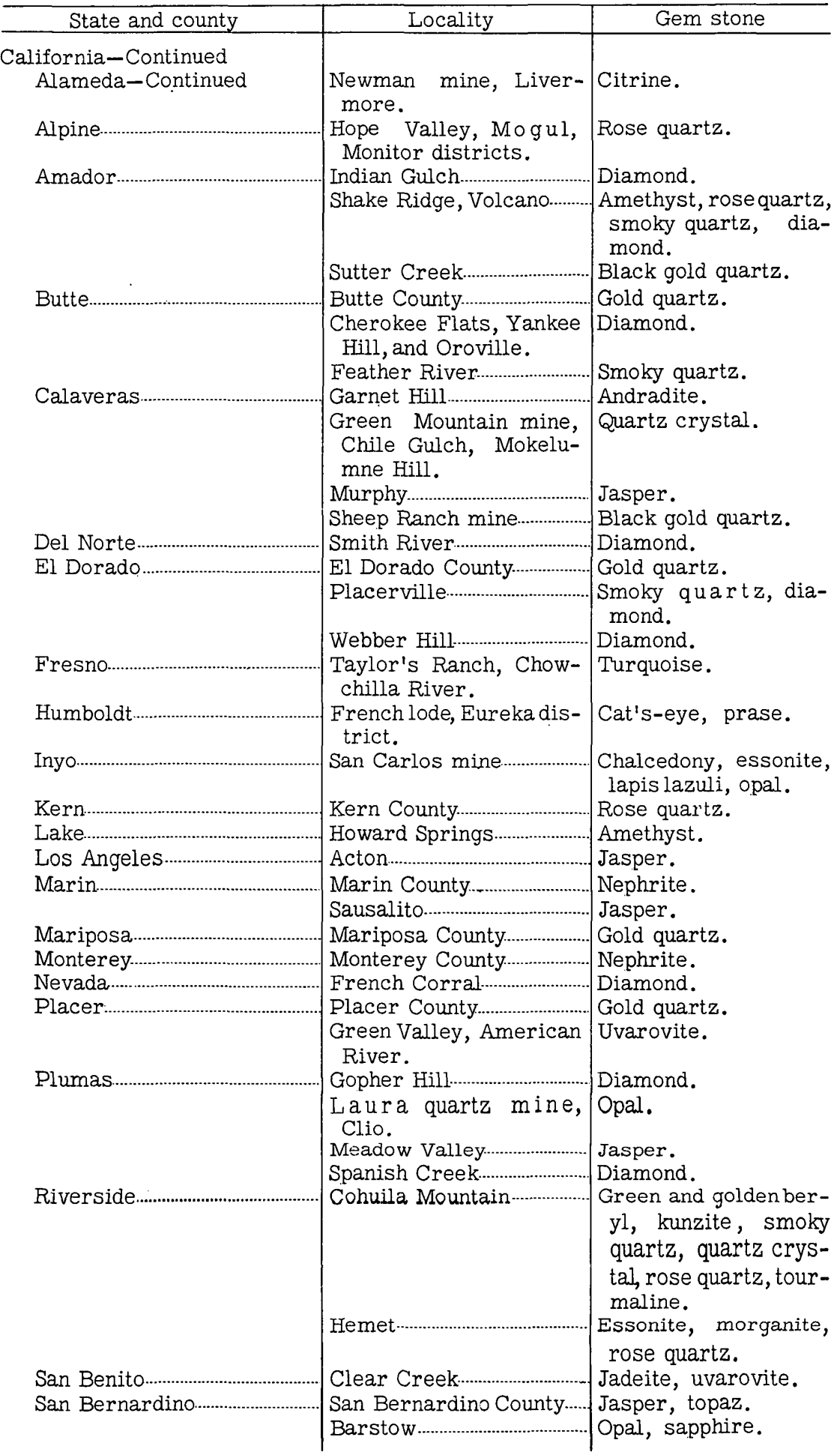


Table-Continued

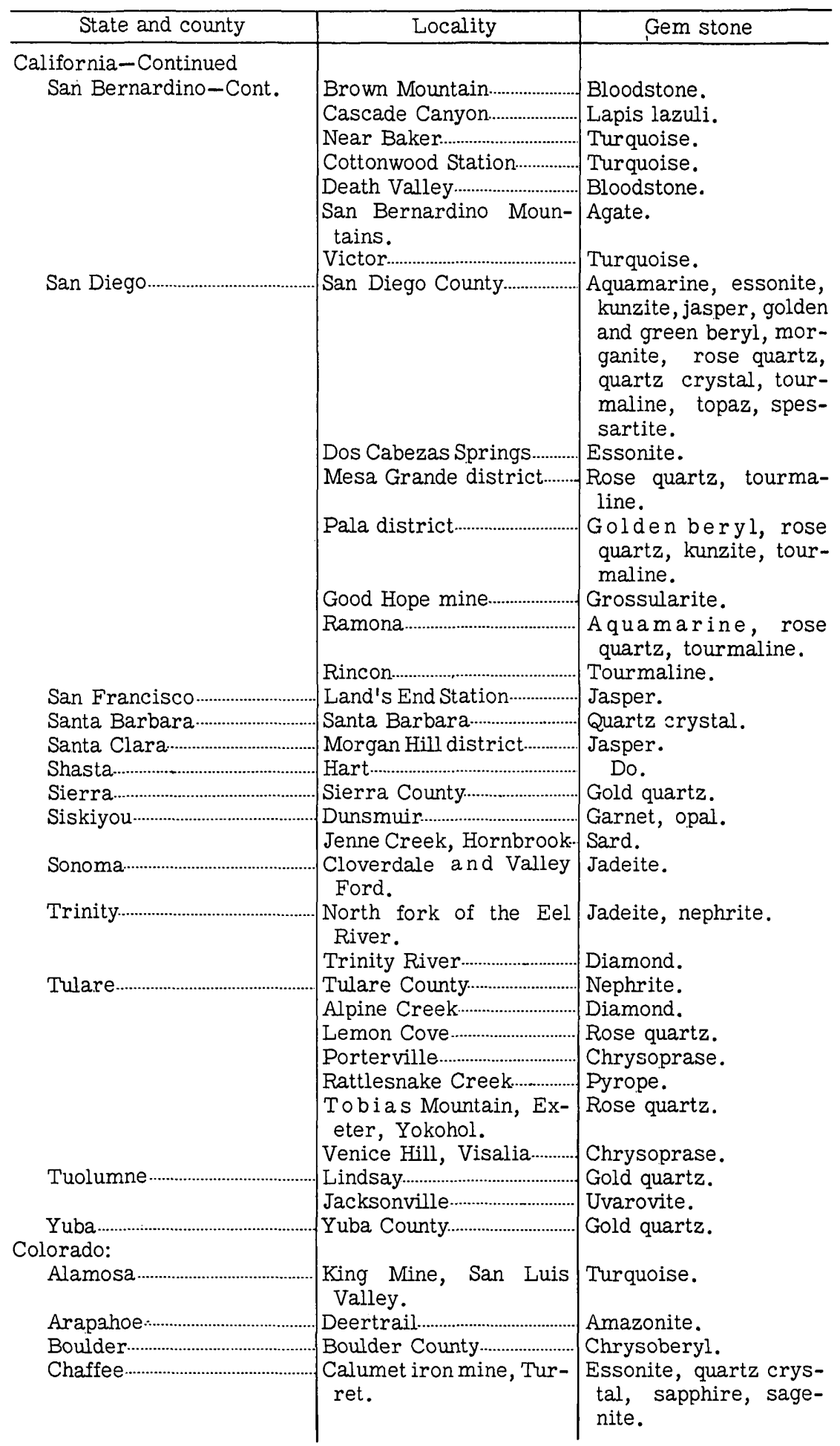


Table-Continued

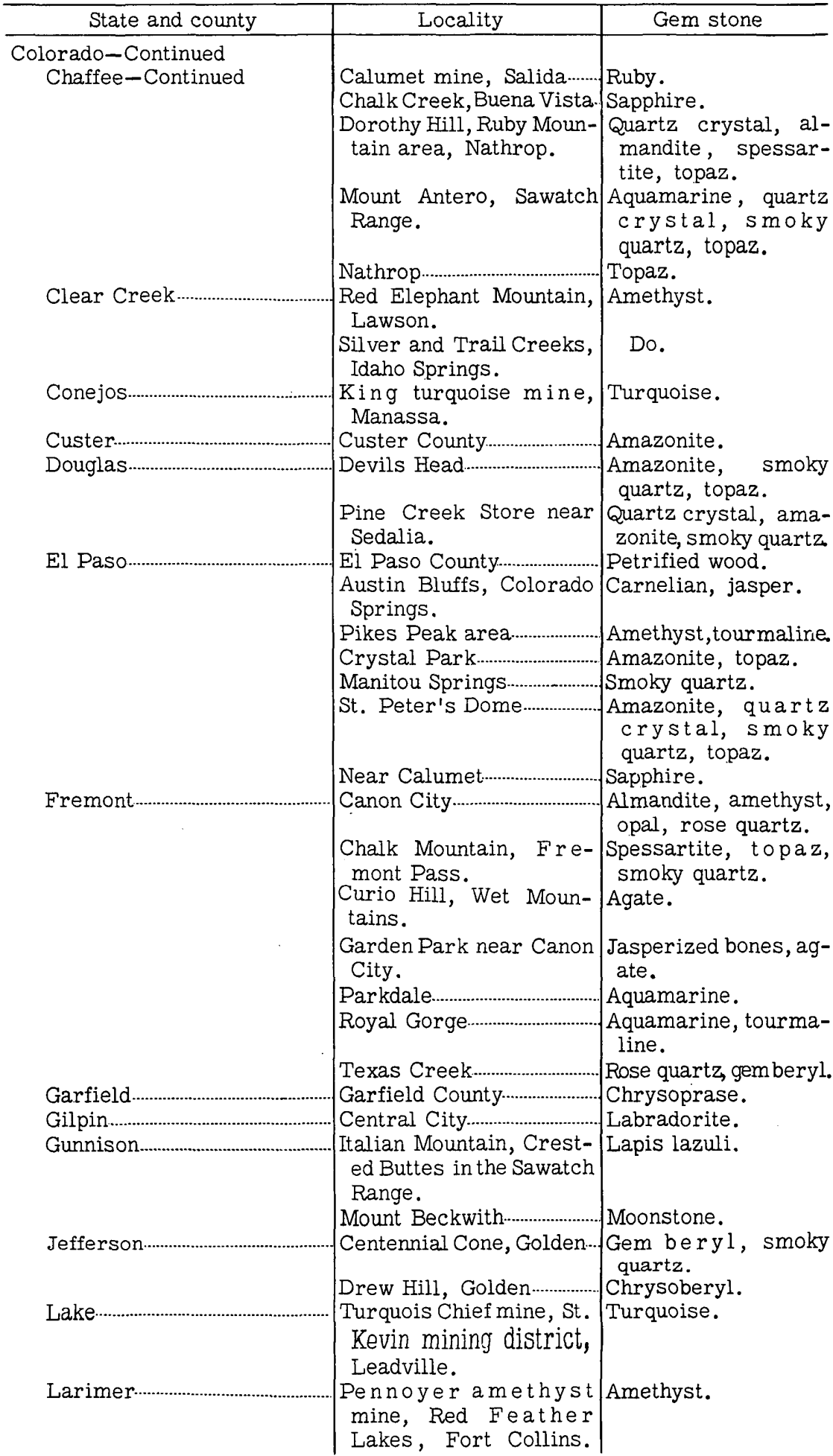




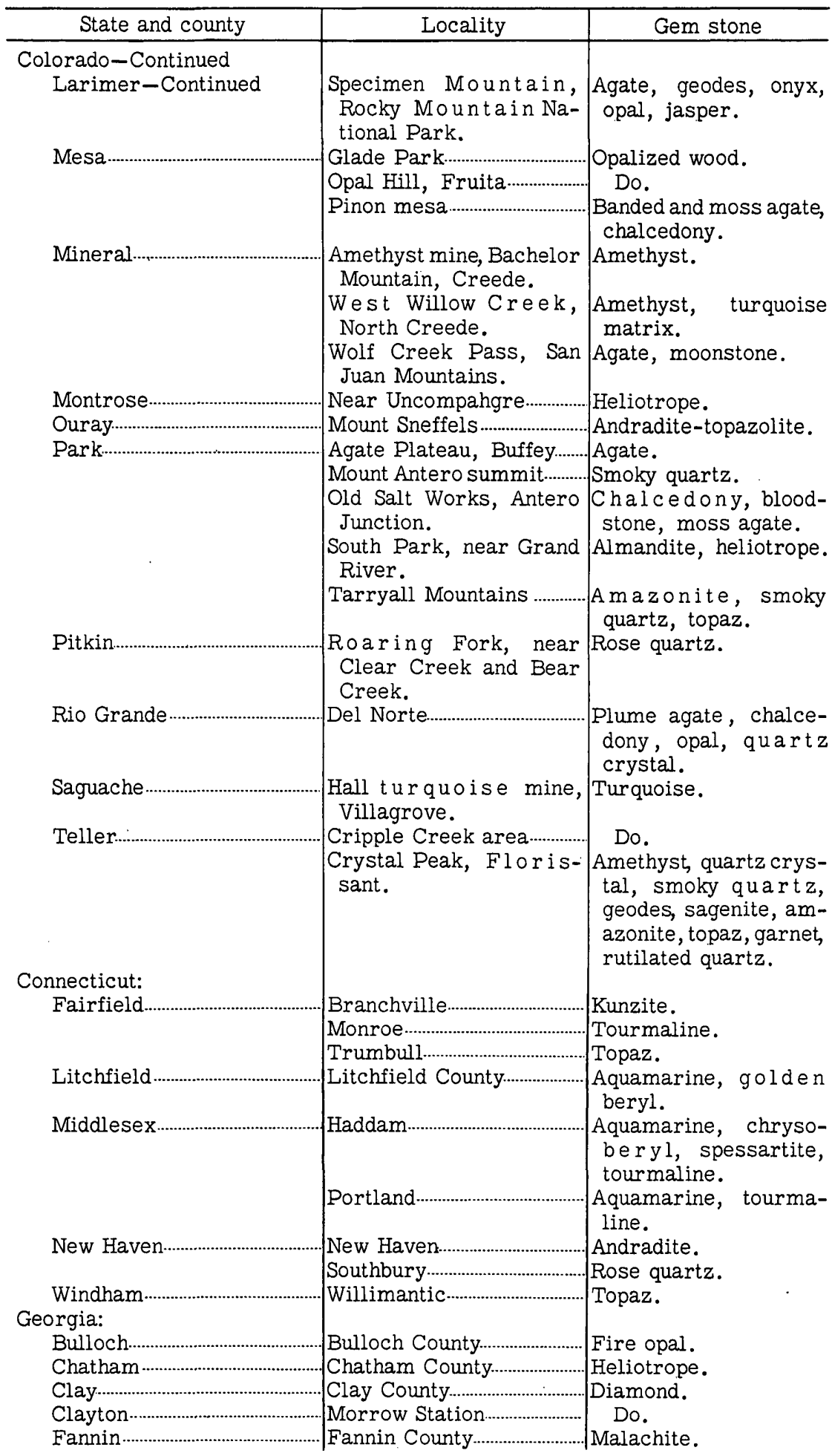


Table-Continued

\begin{tabular}{|c|c|c|}
\hline State and county & Locality & Gem stone \\
\hline Georgia-Continued & \multirow[b]{2}{*}{ Rome } & \multirow{8}{*}{$\begin{array}{l}\text { Quartz crystal. } \\
\text { Do. } \\
\text { Diamond. } \\
\text { Amethyst. } \\
\text { Ruby, sapphire. } \\
\text { Amethyst, aquama - } \\
\text { rine, golden beryl, } \\
\text { quartz crystal. } \\
\text { Amethyst. }\end{array}$} \\
\hline Floyd... & & \\
\hline Franklin & \multirow{5}{*}{ 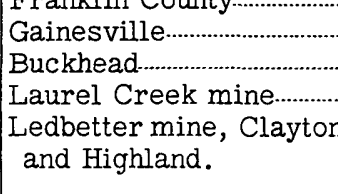 } & \\
\hline Hall............... & & \\
\hline Morgan & & \\
\hline Rabun....... & & \\
\hline & & \\
\hline Towns...... & \multirow{2}{*}{$\begin{array}{l}\text { Old Garrett mine, Char- } \\
\text { lie Creek. } \\
\text { Hightower Bald......................... }\end{array}$} & \\
\hline Union.... & & \multirow{3}{*}{$\begin{array}{l}\text { Do. } \\
\text { Fire opal. }\end{array}$} \\
\hline Washir & \multirow[t]{2}{*}{ 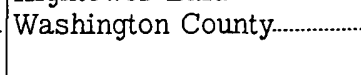 } & \\
\hline Idaho: & & \\
\hline Ada............ & \multirow{4}{*}{$\begin{array}{l}\text { Diamond Basin } \\
\text { Rock Flat gold placer, } \\
\text { Meadows. } \\
\text { Paris Canyon, Humming } \\
\text { Bird mine. } \\
\text { Little Wood River }\end{array}$} & \multirow{2}{*}{$\begin{array}{l}\text { Diamond. } \\
\text { Sapphire. }\end{array}$} \\
\hline Adams.... & & \\
\hline Bear Lake... & & \multirow{7}{*}{$\begin{array}{l}\text { Jasper. } \\
\text { Azurite. } \\
\text { Topaz. } \\
\text { Aquamarine. } \\
\text { Pyrope, spessartite. } \\
\text { Common opal. } \\
\text { Sapphire. }\end{array}$} \\
\hline Blaine. & & \\
\hline Boise. & Boise County & \\
\hline & Centerville.... & \\
\hline & Deadwood Gulch & \\
\hline Canyon & \multirow{5}{*}{ 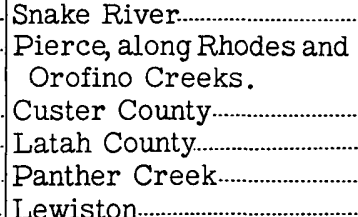 } & \\
\hline Clearwat & & \\
\hline Custer. & & \multirow{7}{*}{$\begin{array}{l}\text { Azurite. } \\
\text { Common opal. } \\
\text { Do. } \\
\text { Almandite, aquama- } \\
\text { rine. } \\
\text { Azurite. } \\
\text { Common opal, pre- } \\
\text { cious opal. } \\
\text { Azurite. }\end{array}$} \\
\hline Latah. & & \\
\hline Lemhi. & & \\
\hline Nez Perce. & Lewiston & \\
\hline Oneida & \multirow{4}{*}{ 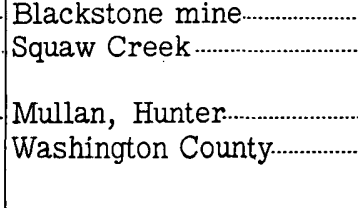 } & \\
\hline Owyhee. & & \\
\hline Shosh & & \\
\hline Washi & & \multirow{2}{*}{$\begin{array}{l}\text { Gem corundum, sap- } \\
\text { phire. }\end{array}$} \\
\hline $\begin{array}{l}\text { Indiana: } \\
\text { Brow }\end{array}$ & & \\
\hline & \multirow{2}{*}{ 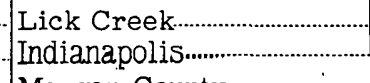 } & \multirow{4}{*}{$\begin{array}{l}\text { Diamond. } \\
\text { Amethyst. } \\
\text { Bronze-colored sap- } \\
\text { phire. } \\
\text { Diamond. }\end{array}$} \\
\hline $\begin{array}{l}\text { Marion } \\
\text { Morgan }\end{array}$ & & \\
\hline Morgar & \multirow{6}{*}{ 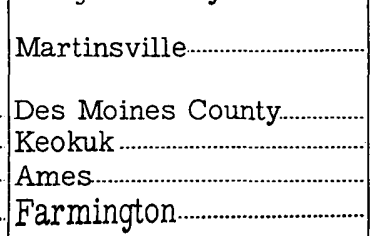 } & \\
\hline wa: & & \\
\hline Des Moin & & \multirow{4}{*}{$\begin{array}{l}\text { Quartz crystal. } \\
\text { Geodes. } \\
\text { Chalcedony. } \\
\text { Geodes. }\end{array}$} \\
\hline Lee ......... & & \\
\hline Story & & \\
\hline Van Buren... & & \\
\hline Kansas: & \multirow[b]{2}{*}{ 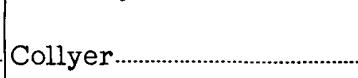 } & \multirow{3}{*}{ Jasper. } \\
\hline $\begin{array}{l}\text { Trego... } \\
\text { Kentucky: }\end{array}$ & & \\
\hline $\begin{array}{l}\text { Kentucky: } \\
\text { Elliott. }\end{array}$ & \multirow{5}{*}{ 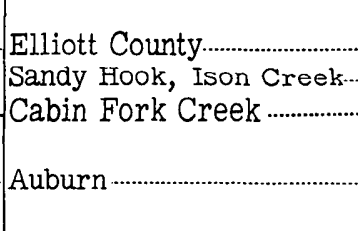 } & \\
\hline Elliott. & & Diamond. \\
\hline Russell..... & & $\begin{array}{l}\text { Pyrope. } \\
\text { Diamond. }\end{array}$ \\
\hline $\begin{array}{l}\text { aine: } \\
\text { Androscoggir }\end{array}$ & & 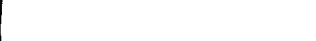 \\
\hline Androscoggin. & & $\begin{array}{l}\text { Golden beryl, smoky } \\
\text { quartz, tourmaline. }\end{array}$ \\
\hline
\end{tabular}


Table-Continued

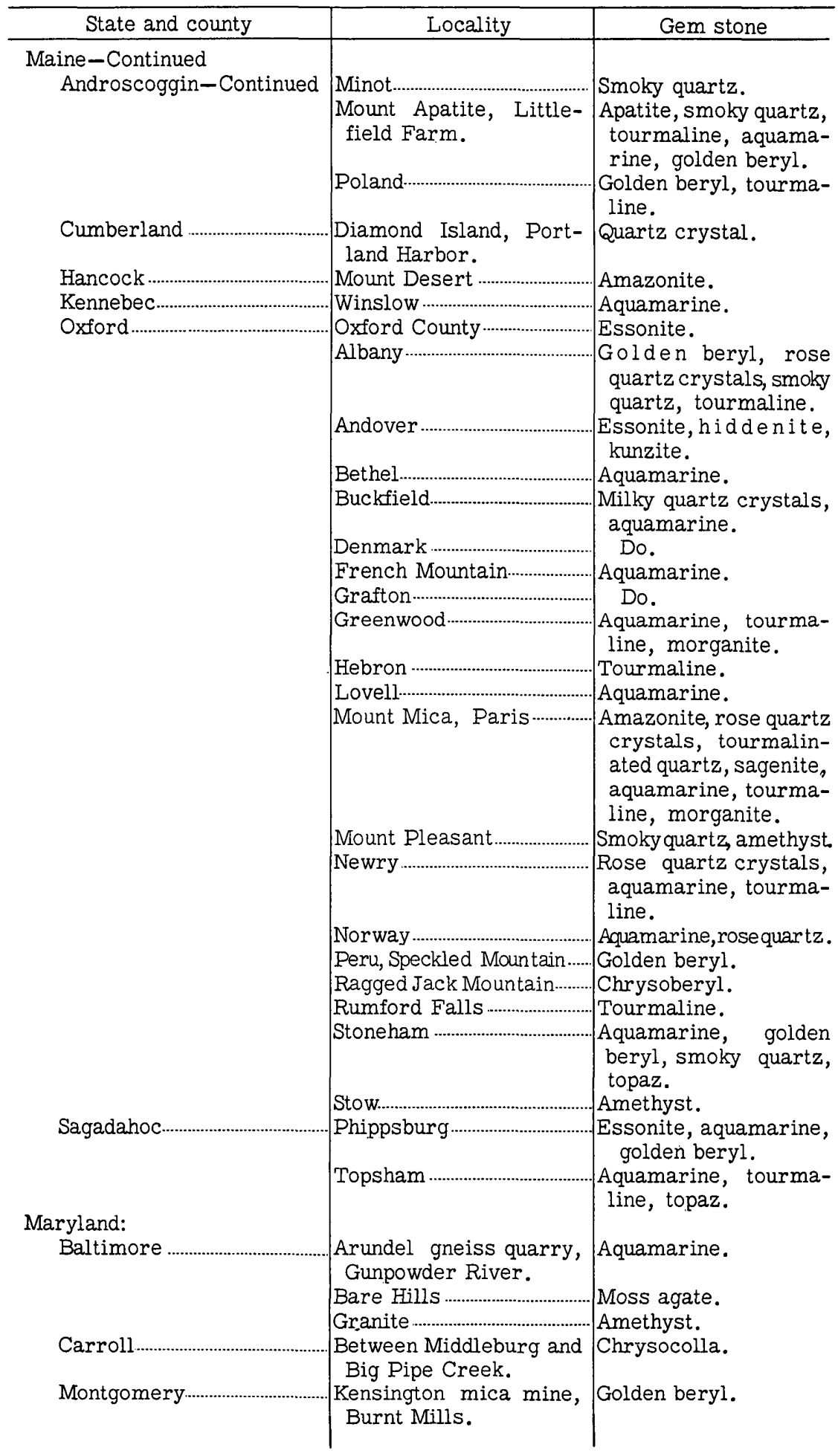


Table-Continued

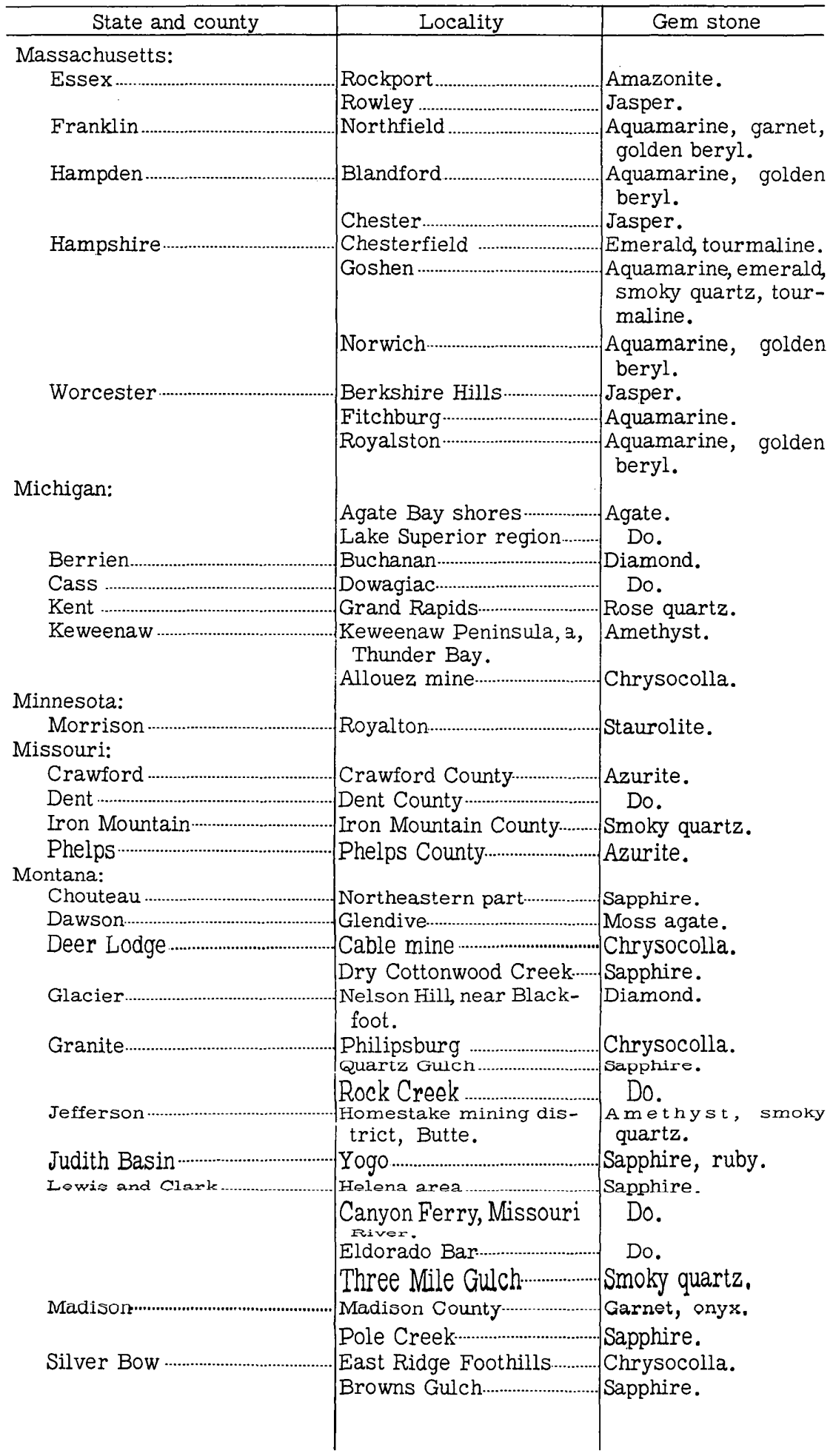


Table-Continued

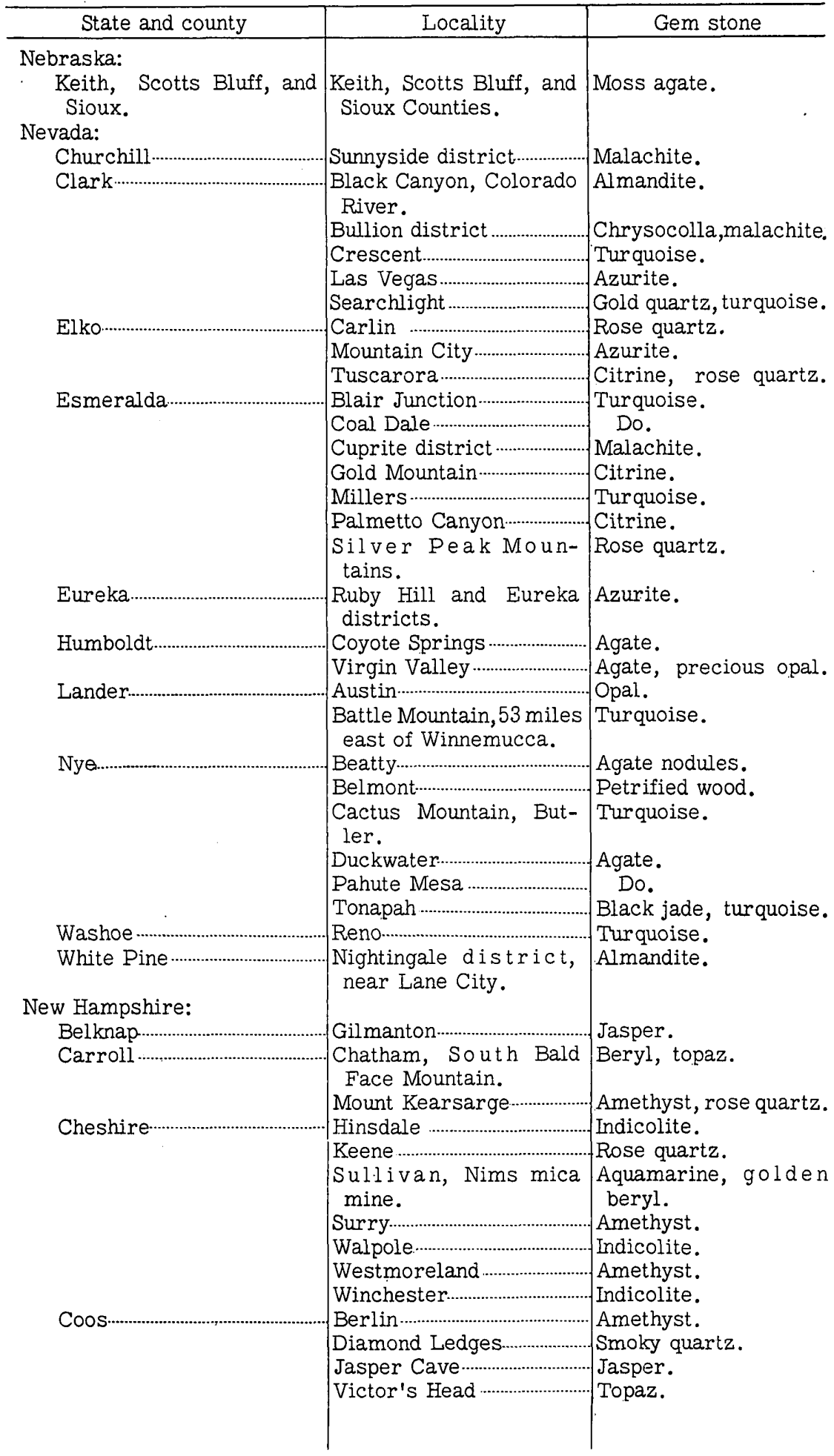


Table-Continued

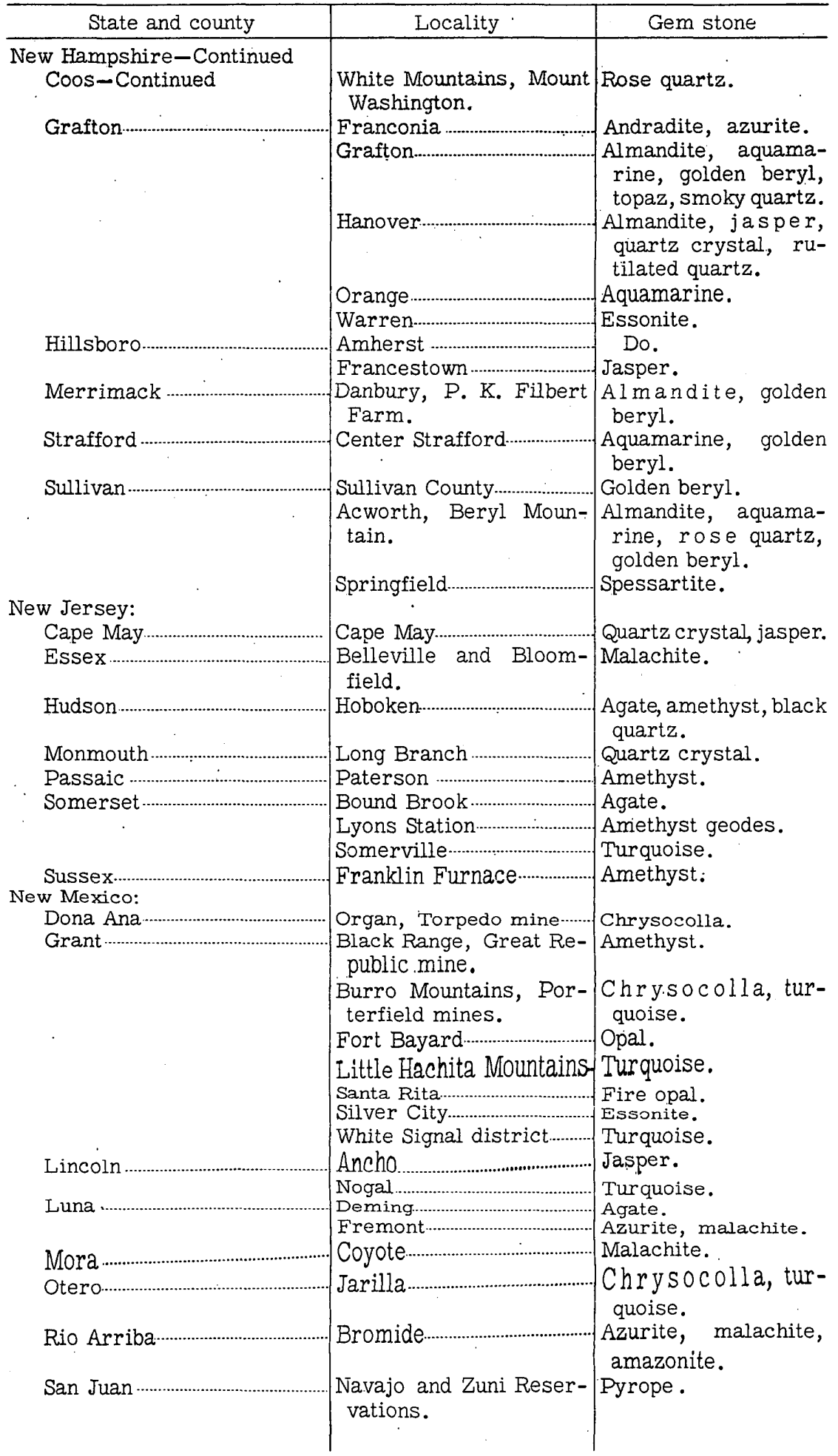


Table-Continued

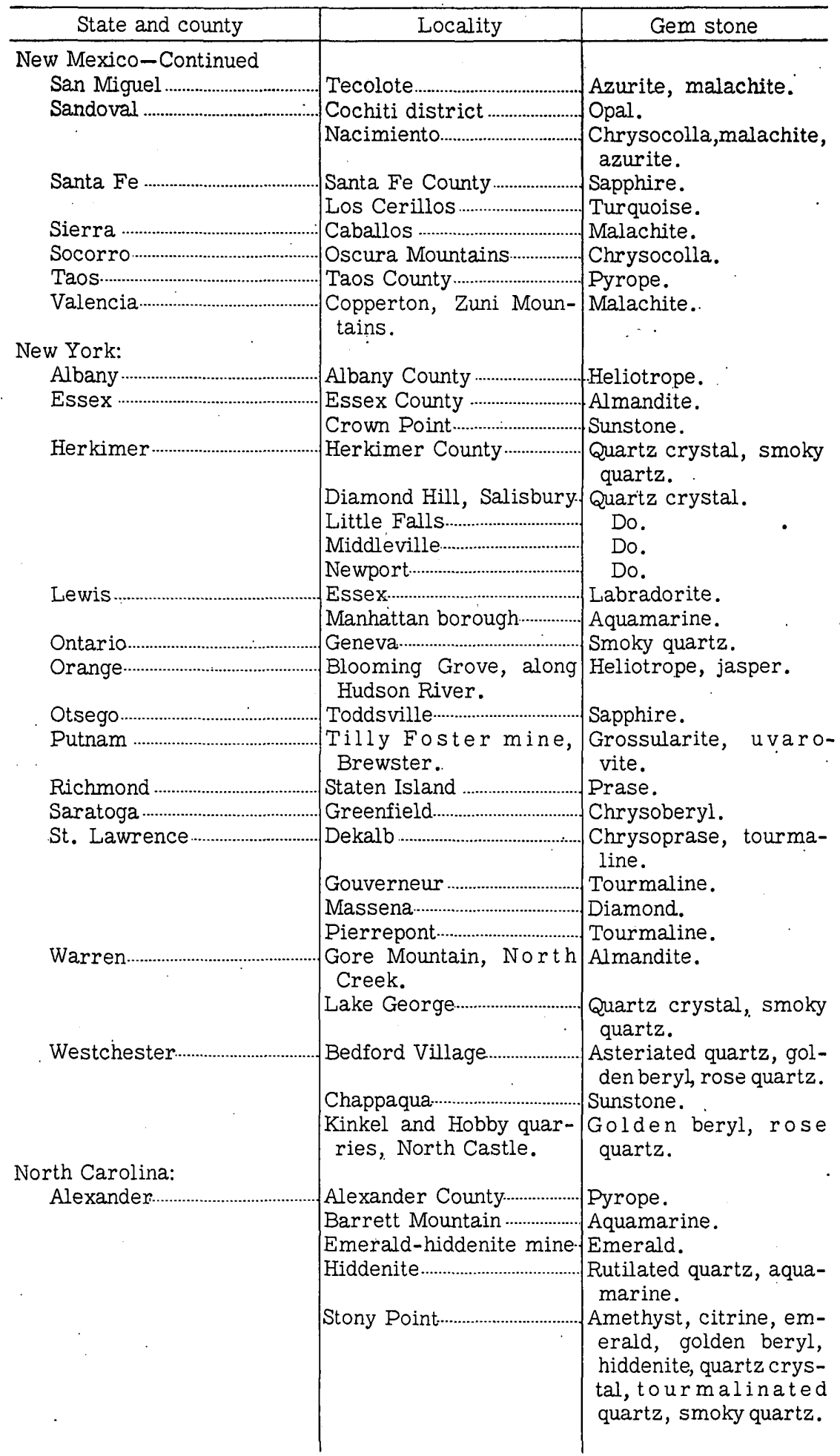


Table-Continued

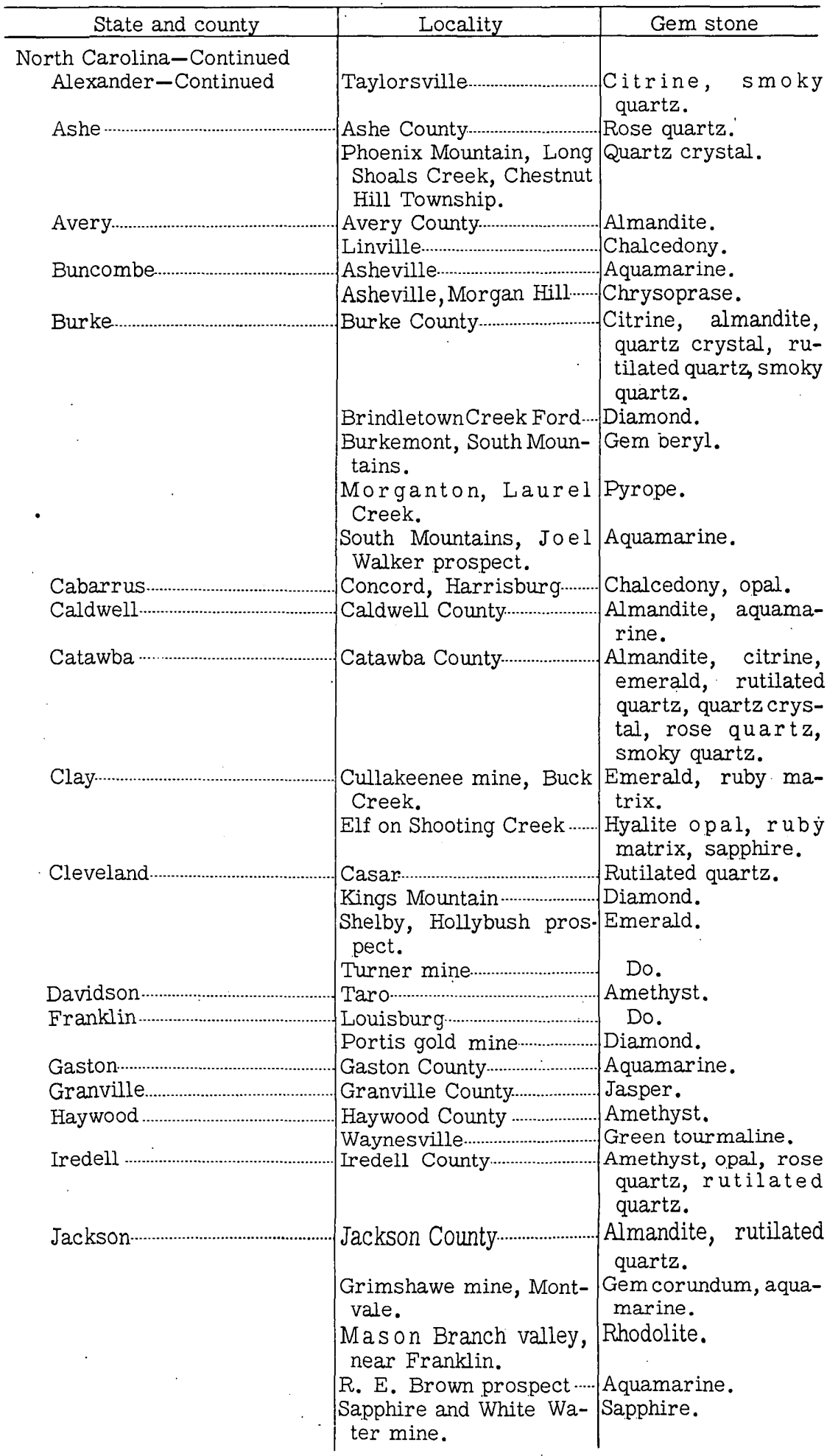


Table-Continued

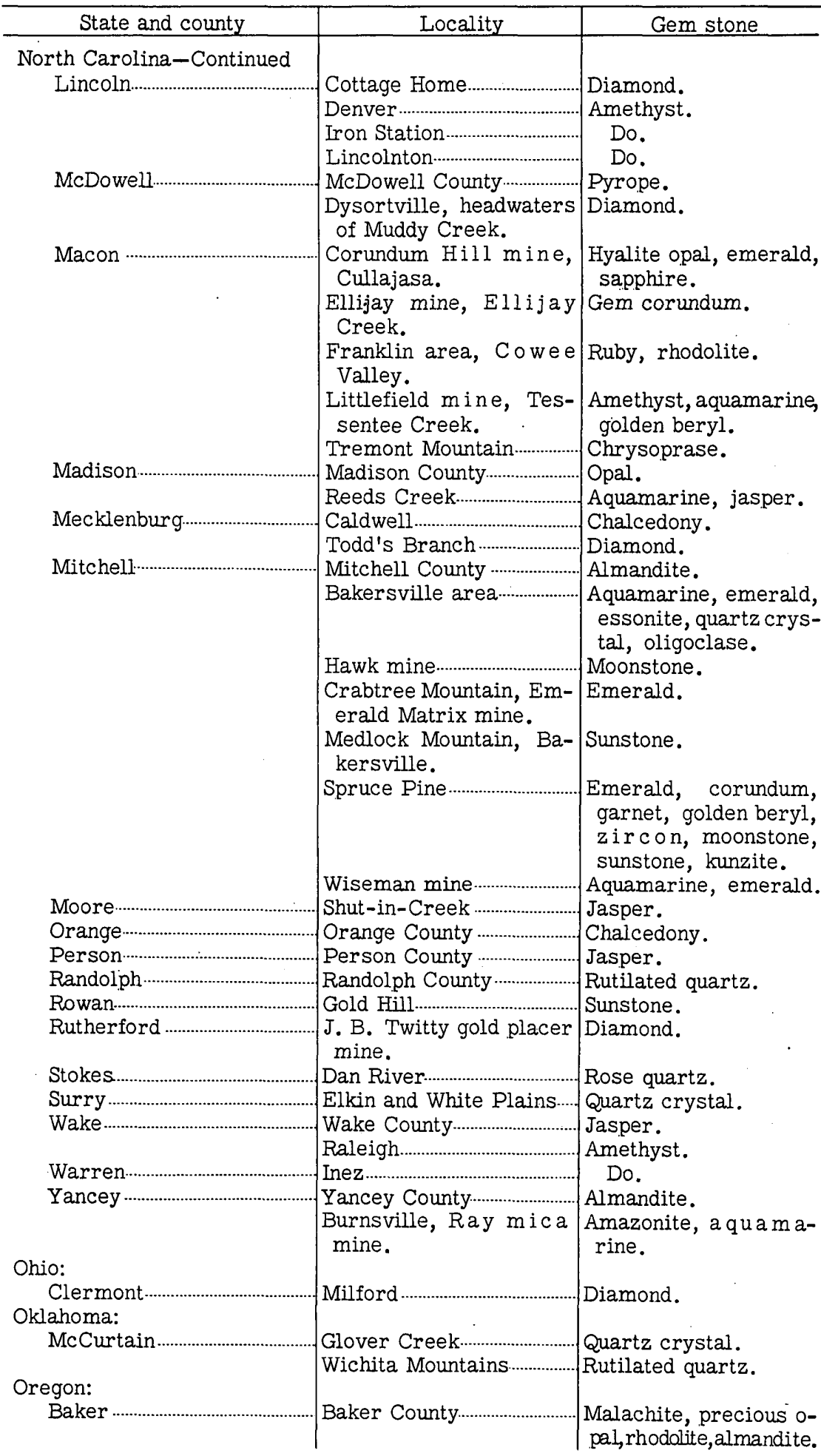


Table-Continued

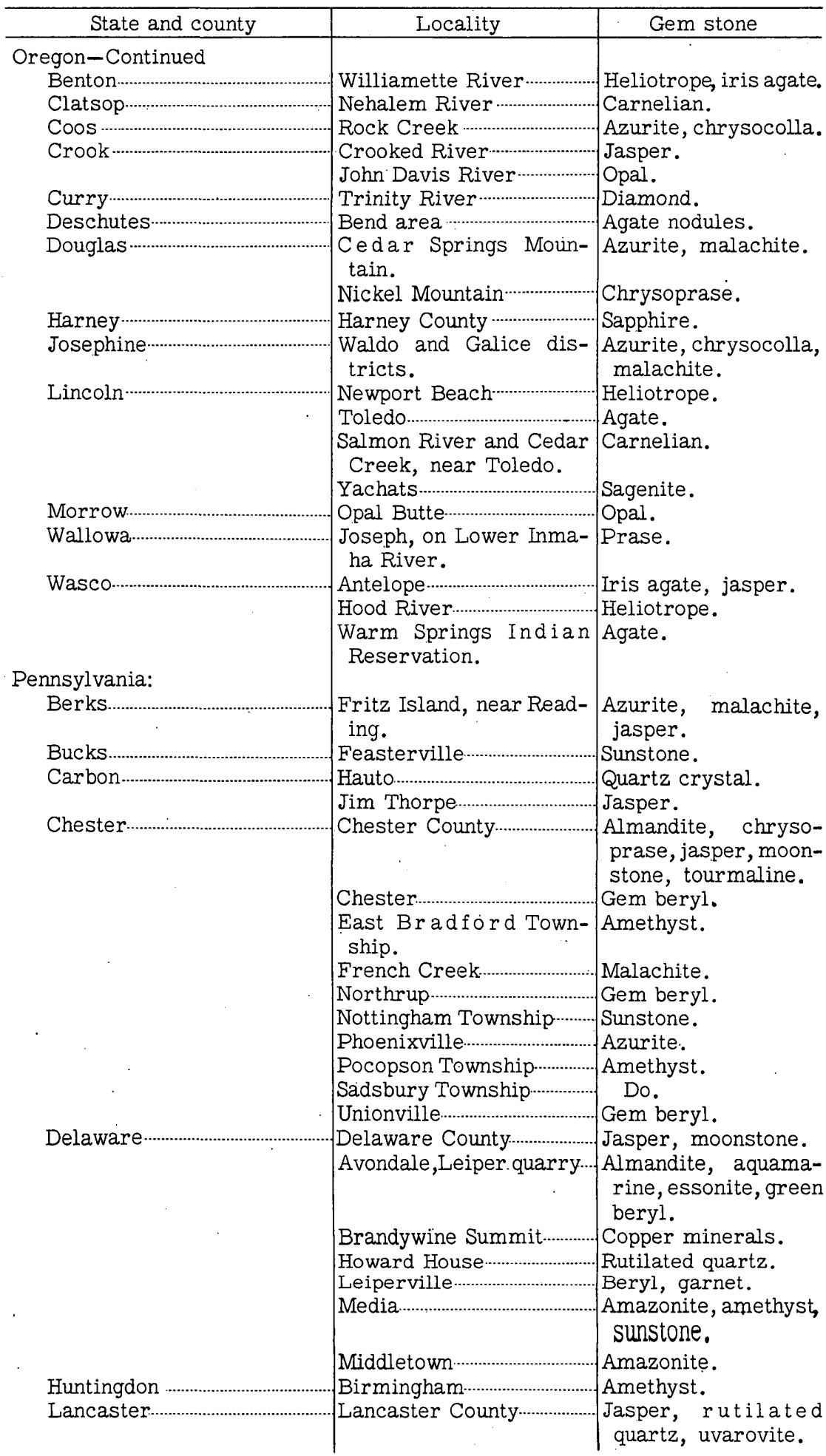


Table-Continued

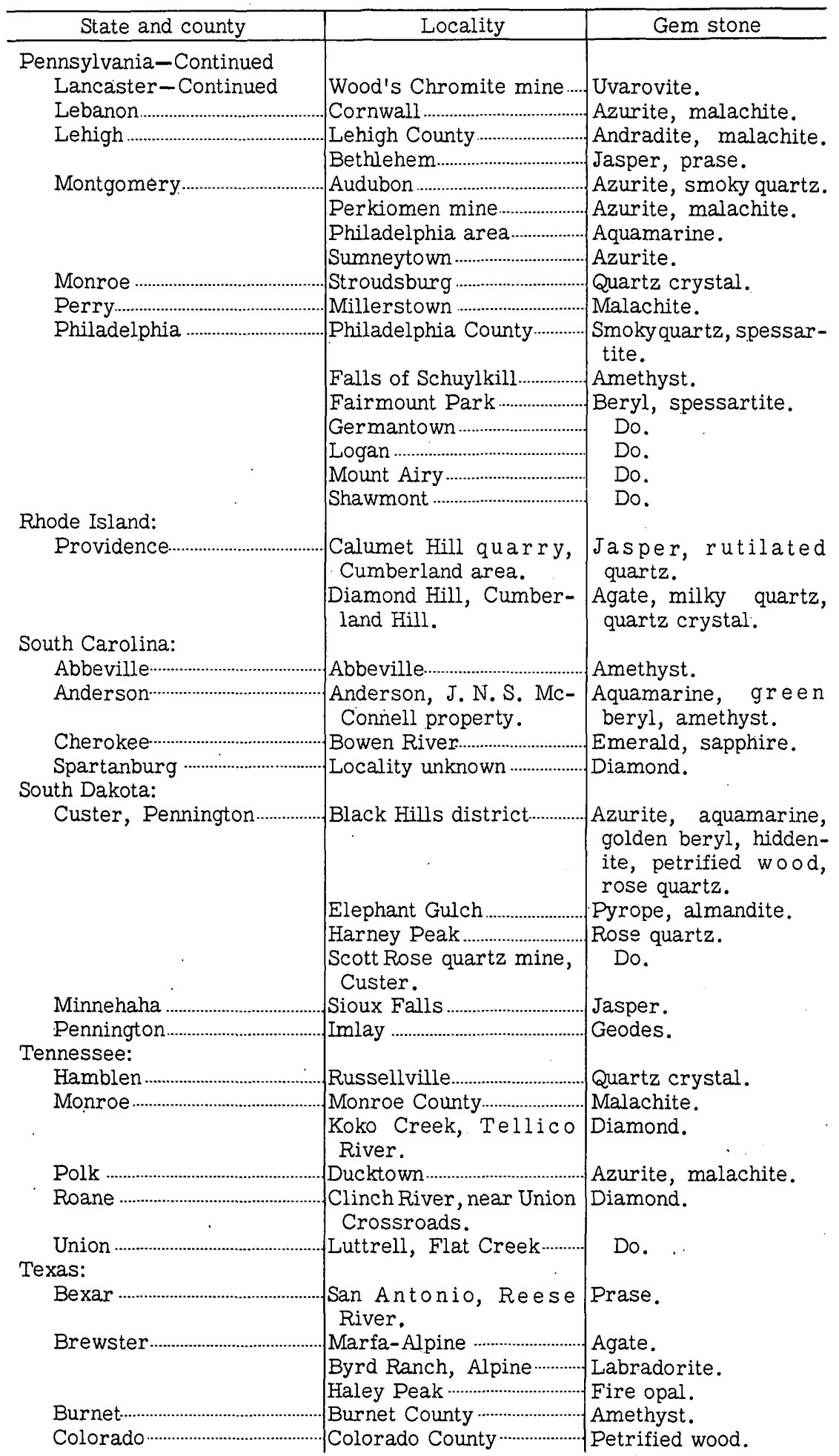


Table-Continued

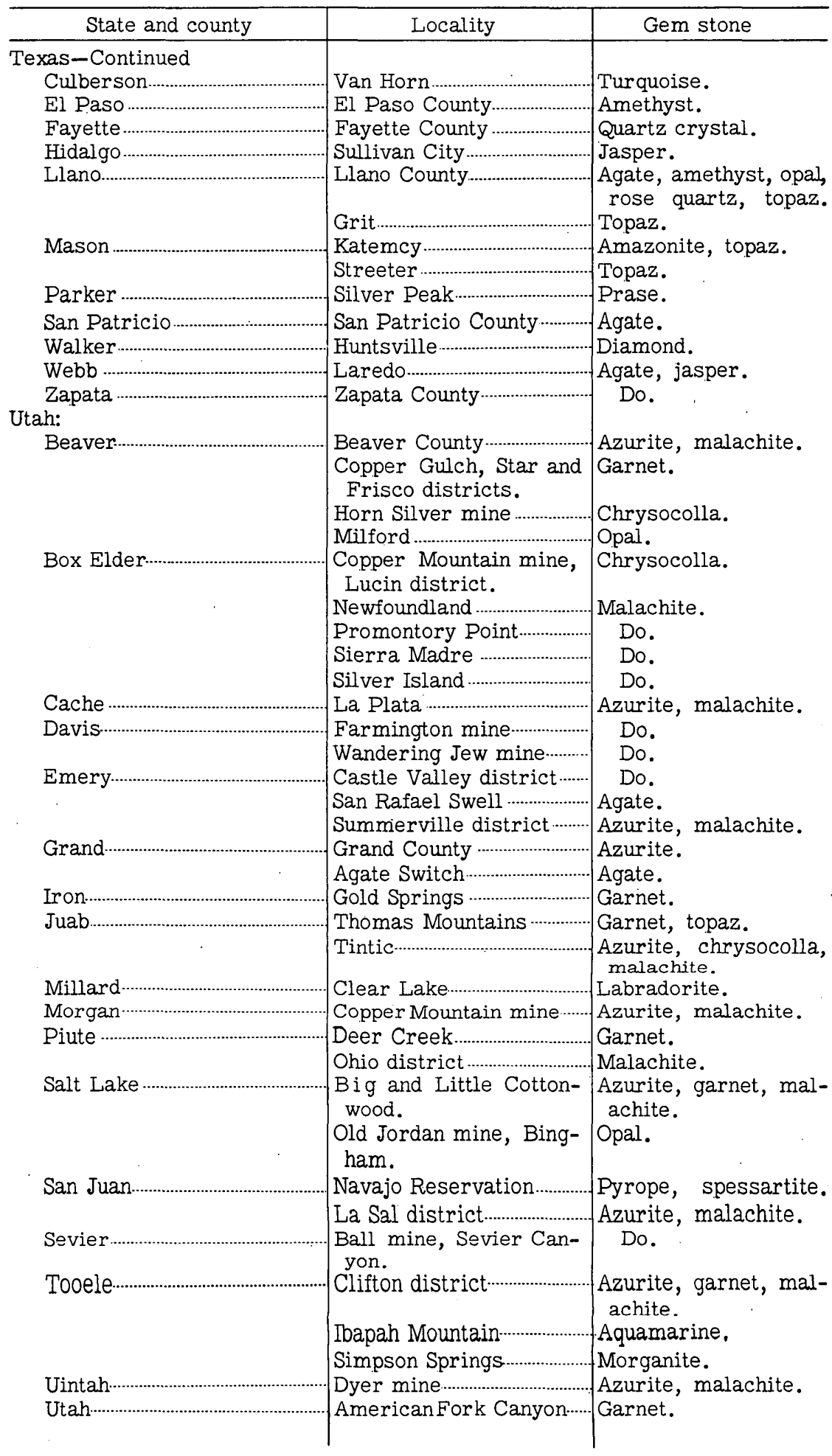


Table-Continued

\begin{tabular}{|c|c|c|}
\hline State and county & Locality & Gem stone \\
\hline \multicolumn{3}{|l|}{ Utah-Continued } \\
\hline Washington....... & Dixie and Silver Reef........ & Azurite. \\
\hline & Lucern Claim & Garnet, malachite. \\
\hline Weber ............ & New Azurite mine ................... & Azurite, malachite. \\
\hline & $\begin{array}{l}\text { Ogden Boilermaker mine } \\
\text { Strongs Canyon }\end{array}$ & Do. \\
\hline \multicolumn{3}{|l|}{ Vermont: } \\
\hline Orange.. & $\begin{array}{l}\text { Copper mines at Corinth, } \\
\text { Copper field, South } \\
\text { Strafford. }\end{array}$ & Malachite. \\
\hline Washington . & 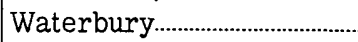 & Rutilated quartz. \\
\hline Windsor & South Royalton & Quartz crystal. \\
\hline \multicolumn{3}{|l|}{ Virginia: } \\
\hline Amelia & Amelia Court House........... & $\begin{array}{l}\text { Amazonite, beryl, ame- } \\
\text { thyst, rutilated quartz, } \\
\text { spes s a t ite, moon- } \\
\text { stone, sunstone, topaz, } \\
\text { tourmaline. }\end{array}$ \\
\hline \multirow[t]{3}{*}{ Amherst..... } & Amherst County.. & Rutilated quartz. \\
\hline & Lowesville ............. & Amethyst. \\
\hline & Fancy Hill....... & Do. \\
\hline \multirow[t]{2}{*}{ Campbell.. } & Campbell County. & Turquoise crystals. \\
\hline & Brookneal & Amethyst. \\
\hline Charlotte ........ & Charlotte Court House.... & Do. \\
\hline Chesterfield & Manchester & Diamond. \\
\hline Fairfax & Fairfax ............... & Gem quartz. \\
\hline Hanover. & Hewlett ................... & Moonstone, sunstone. \\
\hline Henry ....... & Henry County. & Staurolite. \\
\hline Louisa..... & Trevilians ........ & Amethyst. \\
\hline Madison .... & Fishers Gap..................... & Azurite. \\
\hline Mecklenburg & Pontiac mine ........ & Do. \\
\hline Nelson.......... & Nelson County.. & Amethyst. \\
\hline Page ............ & 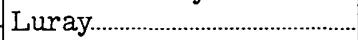 & Azurite. \\
\hline Patrick & Patrick County ...... & Staurolite. \\
\hline Prince William. & Minnieville............... & Amethyst. \\
\hline Rockbridge .............. & 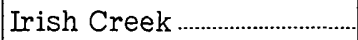 & Beryl. \\
\hline Rockingham .............. & High Knob, Elkton ...... & Azurite. \\
\hline 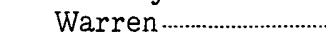 & 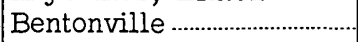 & Do. \\
\hline & Front Royal ............... & Azurite, chrysocolla. \\
\hline Washington: & & \\
\hline Chelan & Crown Point mine........ & Quartz crystal. \\
\hline Clark ................. & Bell Mountain mine........... & Gem quartz. \\
\hline Ferry ….............. & Republic mining district. & Gold. \\
\hline Jefferson...... & Mount Anderson & Gem quartz. \\
\hline & 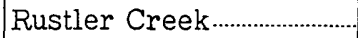 & Do. \\
\hline King & Denny Mountain & Do. \\
\hline Lincoln $\ldots \ldots . . . . . . .$. & 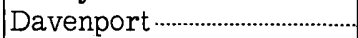 & Precious opal. \\
\hline Pend Oreille.... & Newport & Amethyst. \\
\hline Pierce ……............ & Old Siegmund Ranch......... & Amethystine quartz. \\
\hline Skagit ................ & Sedro Woolley & Nephrite. \\
\hline Skamania ........ & Rainbow & Amethyst. \\
\hline Snohomish ........ & Monte Cristo district......... & Malachite. \\
\hline & Vesper Peak & Essonite. \\
\hline Walla Walla .............. & 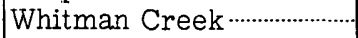 & Opal. \\
\hline Whitman $\cdots$. & $\begin{array}{l}\text { Whelan locality near } \\
\text { Pullman. }\end{array}$ & Precious opal. \\
\hline & Moseslocality, Clarkston & Do. \\
\hline
\end{tabular}


Table-Continued

\begin{tabular}{|c|c|c|}
\hline State and county & Locality & Gem stone \\
\hline $\begin{array}{l}\text { West Virginia: } \\
\text { Monroe......... }\end{array}$ & Peterstown & Diamond. \\
\hline Wisconsin: & & \\
\hline Dane & Oregon ............... & Do. \\
\hline Ozaukee & Saukville ........ & Do. \\
\hline Perce... & Plum Creek. & Do. \\
\hline Racine & Burlington & Do. \\
\hline Washing & 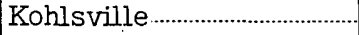 & Do. \\
\hline Waukes & 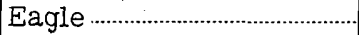 & Do. \\
\hline Wood .. & Grand Rapids & Rose quartz. \\
\hline Wyoming: & & \\
\hline Albany.... & $\begin{array}{l}\text { Holmes, Grand Encamp- } \\
\text { ment district. }\end{array}$ & Azurite, malachite. \\
\hline Carbon. & Sweetwater River & Moss agate, malachite. \\
\hline Crook... & Warrens Peak & Azurite. \\
\hline Fremont & 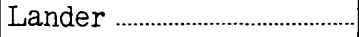 & Nephrite. \\
\hline & Long Creek & Moss agate. \\
\hline & Sage Hen Creek. & Moss agate. \\
\hline Goshen.... & Goshen County .................... & Azurite, garnet, chry- \\
\hline Johnson & Bighorn Mountains ... & Azurite. \\
\hline Laramie... & Chugwater ........................ & Heliotrope. \\
\hline Natrona & Sage Hen Creek ......... & Moss agate. \\
\hline Park …....... & Kirwin & Malachite. \\
\hline Platte & $\begin{array}{l}\text { Wilde and Deercorn } \\
\text { mine, Guernsey. }\end{array}$ & Moss agate. \\
\hline Sweetwater & Eden Valley & Petrified wood. \\
\hline & $\begin{array}{l}\text { Yellowstone National } \\
\text { Park. }\end{array}$ & $\begin{array}{l}\text { Amethyst, agate, pet- } \\
\text { rified wood. }\end{array}$ \\
\hline
\end{tabular}

OTHER GEM STONES IN THE UNITED STATES

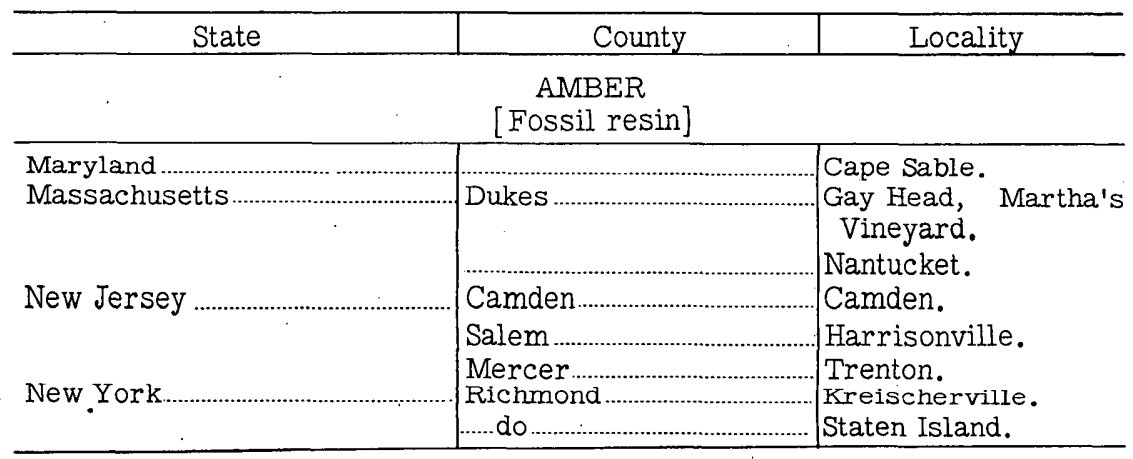

\section{AXINITE}

[Al, $\mathrm{Ca}, \mathrm{Fe}, \mathrm{Mn}$ hydrous borosilicate; honey yellow]

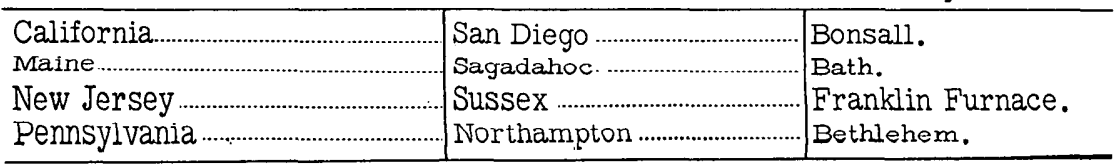


Table-Continued

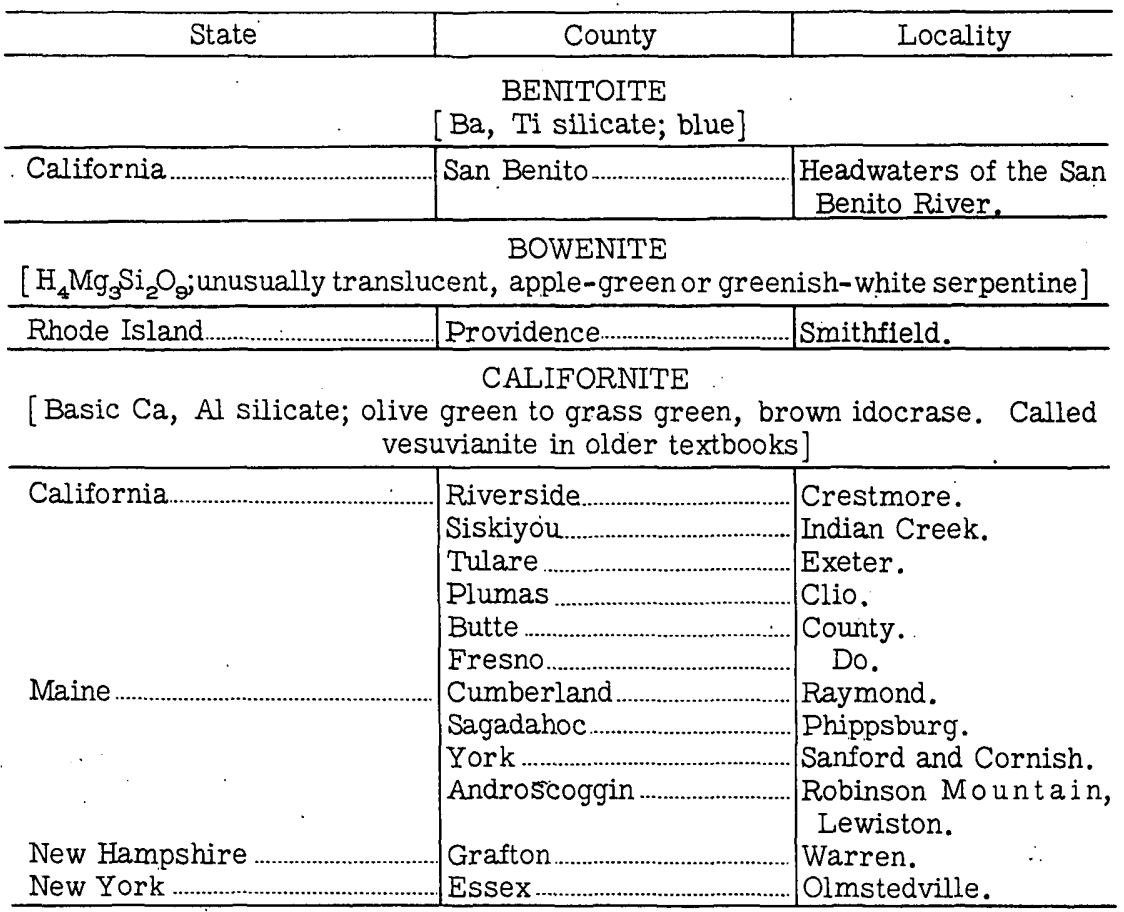

\section{CATLINITE}

[ Compact red clay mineral]

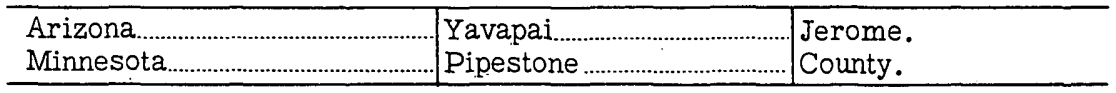

CHIASTOLITE

$\left[\mathrm{Al}_{2} \mathrm{SiO}_{5}\right.$ variety of andalusite with cross in transverse section]

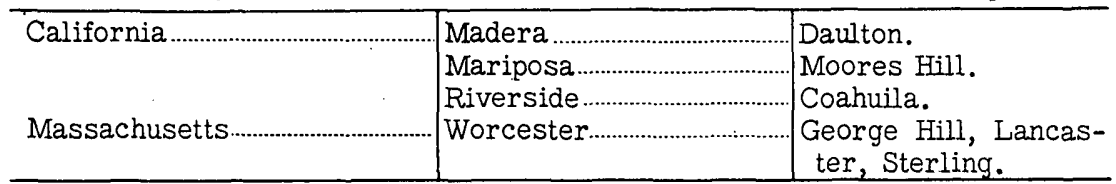

\section{CHLORASTROLITE}

[Translucent to opaque green variety of prehnite or thomsonite]

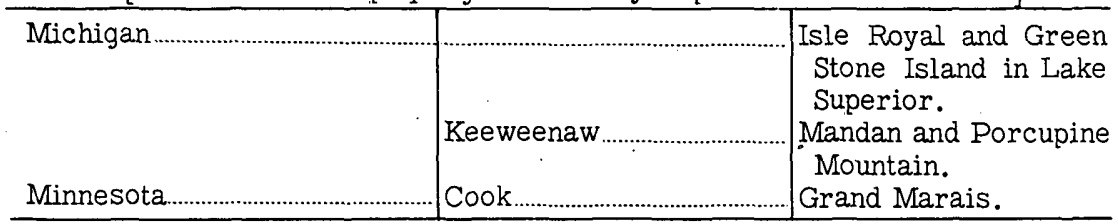

DANBURITE

[ $\mathrm{CaB}_{2}\left(\mathrm{SiO}_{4}\right)_{2}$; wine yellow]

\begin{tabular}{|c|c|c|}
\hline Connecticut & Fairfield.. & Danbury. \\
\hline New York & St. Lawrence... & Russell. \\
\hline
\end{tabular}


Table-Continued

\begin{tabular}{|c|c|c|}
\hline State & County & Locality \\
\hline \multicolumn{3}{|c|}{$\begin{array}{l}\text { ELAEOLITE } \\
{\left[\mathrm{NaAlSiO}_{4} ; \text { flesh, cinnamon, yellow brown, related to nephelite }\right]}\end{array}$} \\
\hline Arkansas & Garland .......................................... & Magnet Cove. \\
\hline \multicolumn{3}{|c|}{$\begin{array}{c}\text { HYACINTH (GEM ZIRCON) } \\
\text { [ } \mathrm{ZrSiO}_{4} \text {; orange, reddish, brownish] }\end{array}$} \\
\hline $\begin{array}{l}\text { Colorado } \\
\text { Maine } \\
\text { Massachusetts } \\
\text { Texas }\end{array}$ & 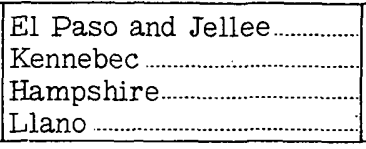 & $\begin{array}{l}\text { Pikes Peak region. } \\
\text { Litchfield. } \\
\text { Chesterfield. } \\
\text { County. }\end{array}$ \\
\hline \multicolumn{3}{|c|}{$\begin{array}{c}\text { PERIDOT } \\
{[\mathrm{Mg}, \text { Fe silicate; dark yellow green }]} \\
\end{array}$} \\
\hline Arizona. & Gila & $\begin{array}{l}\text { Talklai. } \\
\text { Fort Defiance, Zilt- } \\
\text { susayan Butte, Gan- } \\
\text { ada. }\end{array}$ \\
\hline
\end{tabular}

PHENACITE

[ $\mathrm{Be}_{2} \mathrm{SiO}_{4}$; colorless]

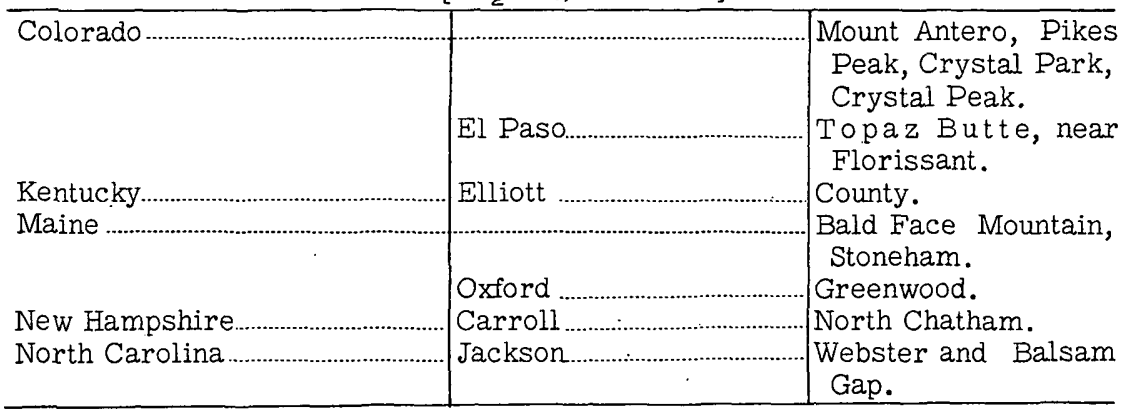

PREHNITE

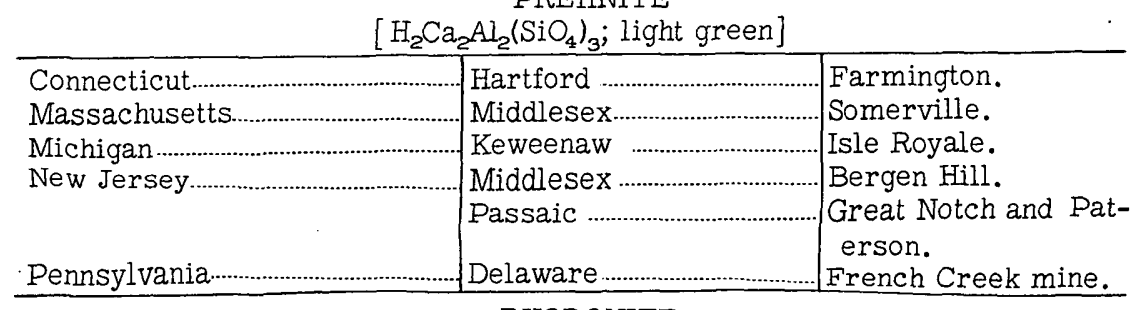

RHODONITE

$\left[\mathrm{MnSiO}_{3}\right.$; red or streaked with black $\mathrm{MnO}$, pink, fleshy, when occurring with rhodochrosite]

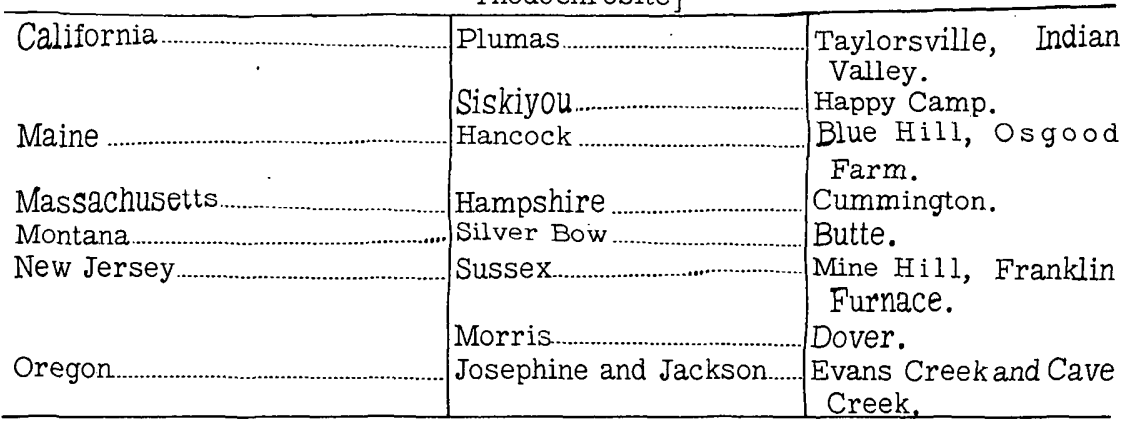


Table-Continued

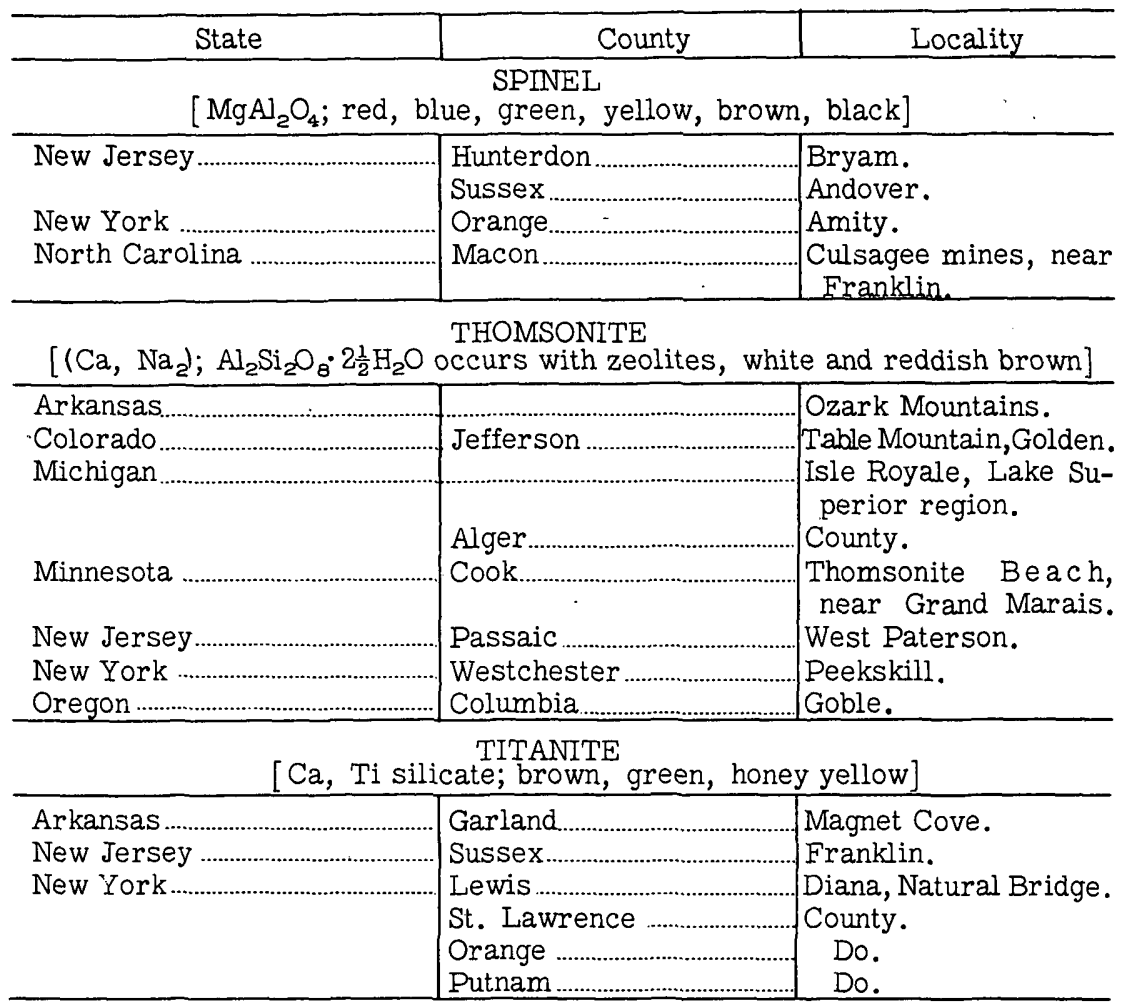

VARISCITE

[ $\mathrm{AlPO}_{4} \cdot 2 \mathrm{H}_{2} \mathrm{O}$; a matrix stone of dark to light green with white phosphatic material, chert, chalcedony]

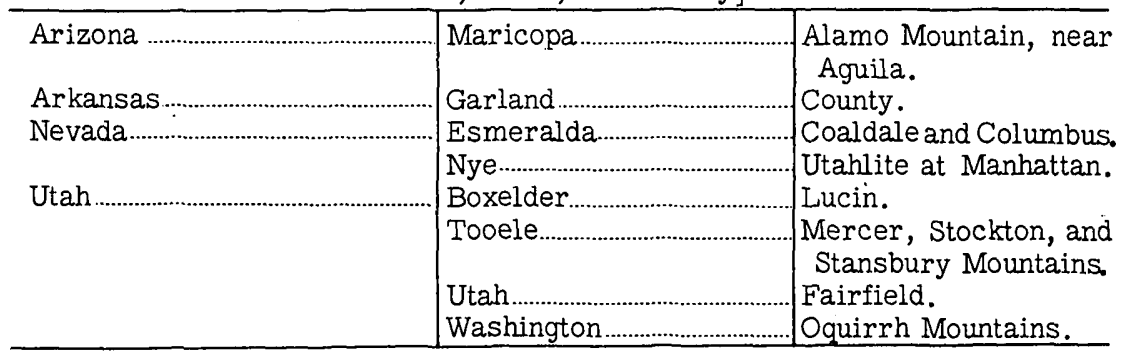

WILLEMITE

[ $\mathrm{Zn}_{2} \mathrm{SiO}_{4}$; white, yellow, green, apple green, flesh red, grayish white, yellowish brown]

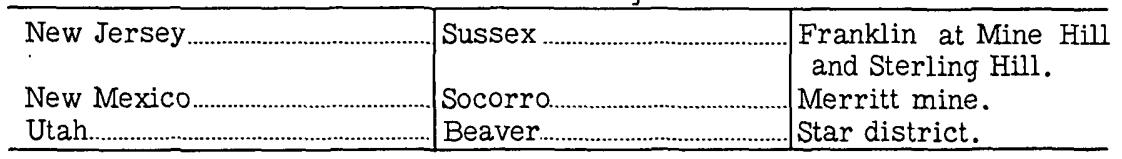

WILLIAMSITE

[Massive, fibrous, foliated, various colors, variety of serpentine, rich blackish oil green]

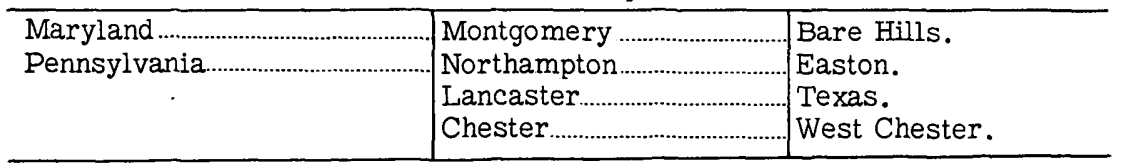




\section{SELECTED BIBLIOGRAPHY}

Adams, J. W., 1953, Beryllium deposits of the Mount Antero region, Chaffee County, Colo.: U. S. Geol. Survey Bull. 982-D.

Anderson, B. W., 1948, Gem testing: New York, Emerson Books, Inc.

Ball, S. H., 1950, A Roman book on precious stones, including an English modernization of the $37 \mathrm{th}$ Book of the Historie of the World by C. Plinius Secundus: Los Angeles, Gemmological Inst. America.

Bateman, A. M. , 1950, Economic mineral deposits: New York, John Wiley \& Sons, Inc., p. 834-854.

Baxter, W. T., 1938, Jewelry, gem cutting, and metalcraft: New York, McGraw-Hill Book Co., Inc.

Briggs, H. E., 1944, An encyclopedia of gems: Los Angeles, Gemmological Inst. America.

Clabaugh, S. E., 1952, Corundum deposits of Montana: U. S. Geol. Survey Bull. 983.

Dake, H. C., 1950, Northwest gem trails: Portland, Oreg., Mineralogist Pub. Co. (Oregon, Washington, Idaho, Montana, and Wyoming). 1951, The agate book: Portland, Oreg., Mineralogist Pub. Co.

Dake, H. C., Fleener, F. L., and Wilson, B. H. , 1938, Quartz family minerals, a handbook for the mineral collector: New York, McGraw-Hill Book Co., Inc.

Fenton, C. L., and Fenton, M. A., 1940, The rock book: New York, Doubleday, Doran \& Co.

Ford, W. E., 1947, Dana's textbook of mineralogy: New York, John Wiley \& Sons, Inc.

Henry, D. J., 1948, California gem trails: Portland, Oreg., Mineralogist Pub. Co.

Hurlburt, C. S., 1952, Dana's manual of mineralogy, 16th ed.: New York, John Wiley \& Sons, Inc.

Kraus, E. H., and Slawson, C. B., 1947, Gems and gem materials, 5th ed.: New York, McGraw-Hill Co., Inc.

Kunz, G. F., 1890, Gems and precious stones of North America, 2d ed.: New York; Scientific Pub. Co.

1905, Gems, jewelers' material, and ornamental stones of California: Calif. Div. Mines Bull. 37.

1913, The curious lore of precious stones; ***: Phila., J. B. Lippincott Co.

McKinley, W. C. , 1939, America gem cabochons, an illustrated handbook of domestic semi-precious stones cut unfaceted: Chicago, Lightner Pub. Co.

Pearl, R. M., 1948, Popular gemology: New York, John Wiley \& Sons, Inc. 1951, Colorado gem trails, revised in 1953: Denver, Sage Books, Inc.

Rogers and Beard, 1947, 5000 years of gems and gemology: Phila., J. B. Lippincott Co.

Sanger, Arthur, and Sanger, Lucille, 1951, Cabochon jewelry making: Peoria, Iil. , Bennett Co.

Shipley, R. M., 1945, Dictionary of gems and gemology: Los Angeles, Gemmological Inst. America.

Smith, G. F. H., 1949, Gemstones: London, Methuen \& Co.

Staatz, M. H., and Bauer, H. L., Jr., 1952, Virgin Valley opal district, Humboldt County, Nev.: U. S. Geol. Survey Circ. 142.

Sterrett, D. B., 1908, Precious stones: Min. Res. U. S., 1907, p. 795-842. 1909, Precious stones: Min. Res. U. S., 1908, p. 861-868.

1910, Gems and precious stones: Min. Res. U. S., 1909, p. 739-808. 1911, Gems and precious stones: Min. Res. U. S., 1910, p. 847-900.

Verrill, A. H. , 1939, Minerals, metals, and gems: Boston, L. C. Page \& Co. Walton, Sir James, 1952, Physical gemmology: New York, Pitman Publishing $\mathrm{Co}$.

Webster, Robert, F. G. A., 1952, Practical gemmology: London, N. A. G. Press Ltd. 
Webster, Robert, and Hinton, Virginia, 1945, Introductory gemology, v. 5 of Jeweler's Library: Los Angeles, Gemmological Inst. America.

Weinstein, Michael, 1939, Precious and semi-precious stones, 3d ed.: New York, Sir Isaac Pitman \& Sons.

Whitlock, H. P., 1940, The story of gems, 2d ed.: New York, Garden City Pub. Co.

0 